\title{
Stereoselective Synthesis of the Bioactive Polypropionates Aureothin, $N$-Acetylaureothamine and Aureonitrile
}

Guangxin Liang, Ian B. Seiple and Dirk Trauner*

Center for New Directions in Organic Synthesis, Department of Chemistry, University of California-Berkeley, Berkeley, California 94720

\section{Supporting Information}

General. Unless otherwise noted, infrared spectra (IR) were obtained on $\mathrm{NaCl}$ plates with a ATI Mattson Gemini FTIR spectrometer. High-resolution mass spectra (HRMS) were obtained on VG ProSpec Mass Spectrometer using electron impact (EI) at $70 \mathrm{eV}$ unless otherwise noted

All reaction mixtures were magnetically stirred in oven-dried glassware under a blanket of nitrogen. External bath temperatures were used to record all reaction mixture temperatures. Analytical thin layer chromatography (TLC) was carried out on Merck silica gel $60 \mathrm{~F}_{254}$ TLC plates. TLC visualization was accomplished using $254 \mathrm{~nm}$ UV light or charring solutions of $\mathrm{KMnO}_{4}$ Flash chromatography was performed on ICN siliTech 32-63 D $60 \AA$ silica gel according to the procedure of Still. ${ }^{1}$

Tetrahydrofuran (THF), dichloromethane $\left(\mathrm{CH}_{2} \mathrm{Cl}_{2}\right)$ were dried according to the procedure described by Bergman. ${ }^{2}$ Benzene was distilled from $\mathrm{CaH}_{2}$ immediately prior to use. DMF was dried over $4 \AA$ molecular sieves. Extracts were dried over anhydrous $\mathrm{MgSO}_{4}$ and solvents were removed with a rotary evaporator at aspirator pressure.

The intermediates which are not shown in the paper are numbered as following:

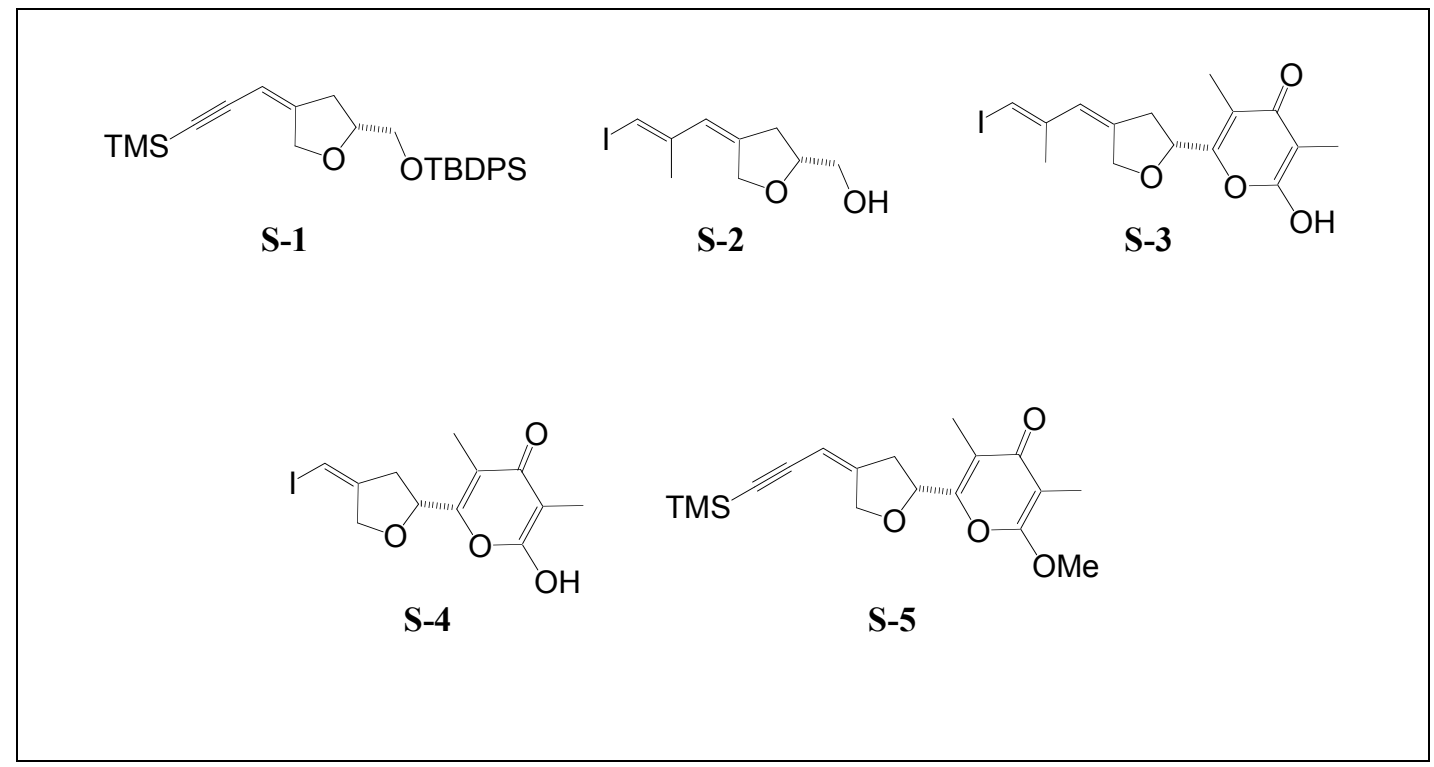

In the cases where same types of reactions were involved, a representative procedure was demonstrated. 


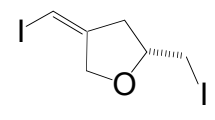

6

\section{2-Iodomethyl-4-iodomethylene-tetrahydro-furan (6)}

To a mixture of (Z)-iodoallylic alcohol 5 (2.05 g, $9.20 \mathrm{mmol}), \mathrm{NaHCO}_{3}(40.0 \mathrm{~g}, 471$ mmol) and $3 \AA$ m.s. in dry $\mathrm{MeCN}(800 \mathrm{~mL})$ at $0{ }^{\circ} \mathrm{C}$ was slowly added a solution of $\mathrm{I}_{2}$ $(6.94 \mathrm{~g}, 27.3 \mathrm{mmol})$ in dry $\mathrm{MeCN}(200 \mathrm{~mL})$. The reaction mixture was stirred violently at $0{ }^{\circ} \mathrm{C}$ for $1 \mathrm{~h}$ and then was allowed to warm to r.t. The reaction mixture was filtered through a pad of Celite and the organic solution was washed with Saturated $\mathrm{Na}_{2} \mathrm{~S}_{2} \mathrm{O}_{3}$ aqueous solution $(200 \mathrm{~mL})$. The aqueous layer was washed with ether $(2 \mathrm{X} 300 \mathrm{~mL})$ and the combined organic layers were washed with brine $(300 \mathrm{~mL})$, dried, filtered and concentrated in vacuo. The product was purified by column chromatography (EtOAc: hexanes $=1: 20)$ to afford $3.10 \mathrm{~g}(97 \%)$ of 6 as colorless oil. $\mathrm{R}_{f} 0.44$ (EtOAc: hexanes $=$ 1:20); IR 3064, 2890, 2843, 1642 $\mathrm{cm}^{-1} ;{ }^{1} \mathrm{H}$ NMR (400 MHz, $\left.\mathrm{CDCl}_{3}\right) \delta_{\mathrm{H}} 6.00$ (t, $1 \mathrm{H}, J=$ $2.0 \mathrm{~Hz}), 4.38(\mathrm{~d}, 1 \mathrm{H}, J=14.6 \mathrm{~Hz}), 4.21(\mathrm{~d}, 1 \mathrm{H}, J=14.6 \mathrm{~Hz}), 4.17$ (m, $1 \mathrm{H}), 3.26-3.17$ $(\mathrm{m}, 2 \mathrm{H}), 2.78(\mathrm{dd}, 1 \mathrm{H}, J=15.9,6.0 \mathrm{~Hz}), 2.42(\mathrm{dd}, 1 \mathrm{H}, J=15.9,7.4 \mathrm{~Hz}) ;{ }^{13} \mathrm{C} \mathrm{NMR}$ $\left(100 \mathrm{MHz}, \mathrm{CDCl}_{3}\right) \delta_{\mathrm{C}} 150.05,80.14,75.86,67.87,40.82,8.24$; HRMS calcd for $\mathrm{C}_{6} \mathrm{H}_{8} \mathrm{I}_{2} \mathrm{O}$ $(\mathrm{M})^{+} 349.8665$, found: 349.8667

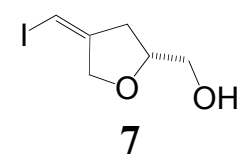

\section{(4-Iodomethylene-tetrahydro-furan-2-yl)-methanol (7)}

A mixture of $\mathrm{CF}_{3} \mathrm{CO}_{2} \mathrm{Cs}(1.75 \mathrm{~g}, 7.11 \mathrm{mmol})$ and $3 \AA \mathrm{m}$. s. $(0.50 \mathrm{~g})$ and $6(0.50 \mathrm{~g}$, $1.43 \mathrm{mmol})$ in dry DMF $(16 \mathrm{~mL})$ was stirred at $90{ }^{\circ} \mathrm{C}$ for $44 \mathrm{~h}$. The reaction mixture was filtered through a pad of Celite into a $\mathrm{NaOH}$ solution $(1 \mathrm{~N}, 200 \mathrm{~mL})$ at $0{ }^{\circ} \mathrm{C}$. The reaction flask and the Celite were rinsed with EtOAc $(300 \mathrm{~mL})$. The two layered were separated and the aqueous layer was washed with EtOAc $(100 \mathrm{~mL})$. The combined organic layers were washed with brine $(50 \mathrm{~mL})$, dried, filtered and concentrated in vacuo. The product was purified by column chromatography (EtOAc: hexanes $=1: 2)$ to afford $0.285 \mathrm{~g}(83 \%)$ of 7 as colorless oil. $\mathrm{R}_{f} 0.40$ (EtOAc: hexanes = 1:2); IR 3390(br), 3063, 2924, 2866, $1663 \mathrm{~cm}^{-1} ;{ }^{1} \mathrm{H}$ NMR $\left(400 \mathrm{MHz}, \mathrm{CDCl}_{3}\right) \delta_{\mathrm{H}} 5.98(\mathrm{t}, 1 \mathrm{H}, J=2.2 \mathrm{~Hz}), 4.35(\mathrm{~d}, 1 \mathrm{H}, J=14.5$ $\mathrm{Hz}), 4.25-4.16(\mathrm{~m}, 2 \mathrm{H}), 3.71(\mathrm{~m}, 1 \mathrm{H}), 3.55$ (m, $1 \mathrm{H}), 2.60(\mathrm{dd}, 1 \mathrm{H}, J=15.9,6.3 \mathrm{~Hz})$, 2.47 (dd, $1 \mathrm{H}, J=15.9,8.6 \mathrm{~Hz}), 2.22(\mathrm{t}, 1 \mathrm{H}, J=6.2 \mathrm{~Hz}) ;{ }^{13} \mathrm{C} \mathrm{NMR}\left(100 \mathrm{MHz}, \mathrm{CDCl}_{3}\right)$ $\delta_{\mathrm{C}} 150.83,81.31,75.52,66.96$ 63.78, 35.96; HRMS calcd for $\mathrm{C}_{6} \mathrm{H}_{9} \mathrm{IO}_{2}(\mathrm{M})^{+}$239.9647, found: 239.9652 


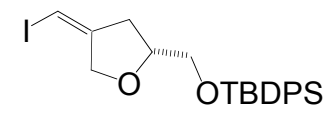

8

tert-Butyl-(4-iodomethylene-tetrahydro-furan-2-ylmethoxy)-diphenyl-silane (8)

To a mixture of imidazole $(0.766 \mathrm{~g}, 11.3 \mathrm{mmol})$ and $7(0.45 \mathrm{~g}, 1.88 \mathrm{mmol})$ in DMF (5 $\mathrm{mL})$ was added TBDPSCl $(1.55 \mathrm{~g}, 5.63 \mathrm{mmol})$. The reaction mixture was stirred for $1 \mathrm{~h}$ and then quenched with water $(50 \mathrm{~mL})$. The mixture was extracted with EtOAc ( $3 \mathrm{X} 50$ $\mathrm{mL})$ and the combined organic layers were washed with brine $(30 \mathrm{~mL})$, dried, filtered and concentrated in vacuo. The product was purified by column chromatography (EtOAc: hexanes $=1: 30)$ to afford $0.852 \mathrm{~g}(95 \%)$ of 8 as colorless oil. $\mathrm{R}_{f} 0.45$ (EtOAc: hexanes $=$ $1: 20)$; IR 3070, 3048, 2929, 2856, 2361, 2337 $\mathrm{cm}^{-1} ;{ }^{1} \mathrm{H}$ NMR $\left(400 \mathrm{MHz}, \mathrm{CDCl}_{3}\right) \delta_{\mathrm{H}} 7.71-$ $7.66(\mathrm{~m}, 4 \mathrm{H}), 7.45-7.37(\mathrm{~m}, 6 \mathrm{H}), 5.96(\mathrm{~m}, 1 \mathrm{H}), 4.38(\mathrm{~d}, 1 \mathrm{H}, J=14.5 \mathrm{~Hz}), 4.31(\mathrm{~m}, 1$ H), $4.25(\mathrm{~m}, 1 \mathrm{H}), 3.72(\mathrm{~d}, 2 \mathrm{H}, J=4.6 \mathrm{~Hz}), 2.72-2.65(\mathrm{~m}, 1 \mathrm{H}), 2.61-2.53(\mathrm{~m}, 1 \mathrm{H}), 1.08$ $(\mathrm{s}, 9 \mathrm{H}) ;{ }^{13} \mathrm{C} \mathrm{NMR}\left(100 \mathrm{MHz}, \mathrm{CDCl}_{3}\right) \delta_{\mathrm{C}} 151.52,135.66,133.42,129.78,127.78,81.28$, $75.88,66.29,66.00,36.95,26.90,19.32$

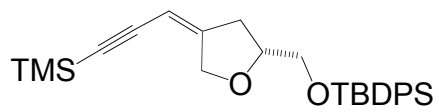

S-1

2-(tert-Butyl-diphenyl-silanyloxymethyl)-4-(3-trimethylsilanyl-prop-2-ynylidene)tetrahydro-furan (S-1)

A mixture of $8(0.760 \mathrm{~g}, 1.59 \mathrm{mmol})$, TMSA $(0.466 \mathrm{~g}, 4.76 \mathrm{mmol}), \mathrm{Pd}\left(\mathrm{PPh}_{3}\right)_{2} \mathrm{Cl}_{2}(0.112 \mathrm{~g}$, $0.159 \mathrm{mmol}), \mathrm{CuI}(0.060 \mathrm{~g}, 0.32 \mathrm{mmol})$ in THF $(10 \mathrm{~mL})$ and $\mathrm{NEt}_{3}(10 \mathrm{~mL})$ was heated at $70{ }^{\circ} \mathrm{C}$ for $5 \mathrm{~h}$. The reaction mixture was cooled to r.t. and was then diluted with EtOAc $(100 \mathrm{~mL})$ and the mixture was filtered through a pad of Celite. The reaction flask and the Celite were rinsed with EtOAc $(50 \mathrm{~mL})$ and the combined organic filtrates were washed with brine $(30 \mathrm{~mL})$, dried, filtered and concentrated in vacuo. The product was purified by column chromatography (EtOAc: hexanes $=1: 30)$ to afford $0.685 \mathrm{~g}(96 \%)$ of $\mathbf{S - 1}$ as colorless oil. $\mathrm{R}_{f} 0.34$ (EtOAc: hexanes = 1:20); IR 3071, 3049, 2957, 2930, 2897, 2858, 2168, $2121 \mathrm{~cm}^{-1} ;{ }^{1} \mathrm{H}$ NMR $\left(400 \mathrm{MHz}, \mathrm{CDCl}_{3}\right) \delta_{\mathrm{H}} 7.71-7.66(\mathrm{~m}, 4 \mathrm{H}), 7.45-7.37(\mathrm{~m}, 6 \mathrm{H})$, 5.49 (t, $1 \mathrm{H}, J=2.4 \mathrm{~Hz}), 4.63(\mathrm{~d}, 1 \mathrm{H}, J=15.2 \mathrm{~Hz}), 4.49$ (d, $1 \mathrm{H}, J=15.2 \mathrm{~Hz}), 4.20$ (m, 1 H), $3.72(\mathrm{~d}, 2 \mathrm{H}, J=4.6 \mathrm{~Hz}), 2.75-2.69(\mathrm{~m}, 1 \mathrm{H}), 2.64-2.58(\mathrm{~m}, 1 \mathrm{H}), 1.08(\mathrm{~s}, 9 \mathrm{H}), 0.20$ $(\mathrm{s}, 9 \mathrm{H}) ;{ }^{13} \mathrm{C} \mathrm{NMR}\left(100 \mathrm{MHz}, \mathrm{CDCl}_{3}\right) \delta_{\mathrm{C}} 156.62,135.61,135.60,133.43,133.39,129.70$, $129.67,127.70,101.79,99.89,98.60,79.97,71.32,65.83,35.02,26.80,19.24,0.04$ 


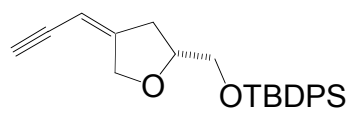

9

\section{tert-Butyl-[4-(2-methyl-allylidene)-tetrahydro-furan-2-ylmethoxy]-diphenyl-silane} (9)

To a mixture of S-1 $(0.720 \mathrm{~g}, 1.61 \mathrm{mmol})$ in $\mathrm{MeOH}(12 \mathrm{~mL})$ and $\mathrm{CH}_{2} \mathrm{Cl}_{2}(12 \mathrm{~mL})$ was added $\mathrm{K}_{2} \mathrm{CO}_{3}(3.33 \mathrm{~g}, 24.2 \mathrm{mmol})$ at $0^{\circ} \mathrm{C}$. The reaction mixture was allowed to warm to r.t. and was stirred for $2 \mathrm{~h}$. The reaction mixture was then partitioned between water ( 50

$\mathrm{mL})$ and $\mathrm{CH}_{2} \mathrm{Cl}_{2}(100 \mathrm{~mL})$. The aqueous layer was washed with $\mathrm{CH}_{2} \mathrm{Cl}_{2}(2 \mathrm{X} 30 \mathrm{~mL})$ and the combined organic layers were washed with brine $(40 \mathrm{~mL})$, dried, filtered and concentrated in vacuo. The product was purified by column chromatography (EtOAc: hexanes $=1: 20)$ to afford $0.600 \mathrm{~g}(99 \%)$ of 9 as colorless oil. $\mathrm{R}_{f} 0.28$ (EtOAc: hexanes $=$ $1: 20)$; IR 3305, 3289, 3071, 2930, 2857 $\mathrm{cm}^{-1} ;{ }^{1} \mathrm{H}$ NMR (400 $\left.\mathrm{MHz}, \mathrm{CDCl}_{3}\right) \delta_{\mathrm{H}}$ 7.76-7.73 (m, $4 \mathrm{H}), 7.49-7.41(\mathrm{~m}, 6 \mathrm{H}), 5.48(\mathrm{~m}, 1 \mathrm{H}, J=2.4 \mathrm{~Hz}), 4.69$ (d, $1 \mathrm{H}, J=15.2 \mathrm{~Hz}), 4.55$ $(\mathrm{d}, 1 \mathrm{H}, J=15.2 \mathrm{~Hz}), 4.25(\mathrm{~m}, 1 \mathrm{H}), 3.79$ (d, $2 \mathrm{H}, J=4.6 \mathrm{~Hz}), 3.12(\mathrm{~s}, 1 \mathrm{H}), 2.76(\mathrm{dd}, 1 \mathrm{H}$, $J=16.8,6.8 \mathrm{~Hz}), 2.66(\mathrm{dd}, 1 \mathrm{H}, J=16.8,6.8 \mathrm{~Hz}), 1.13(\mathrm{~s}, 9 \mathrm{H}) ;{ }^{13} \mathrm{C}$ NMR $(100 \mathrm{MHz}$, $\left.\mathrm{CDCl}_{3}\right) \delta_{\mathrm{C}} 157.17,135.65,133.45,133.43,129.78,127.76,127.78,98.81,81.46,80.35$, $80.00,71.30,65.92,35.03,26.88,19.30$

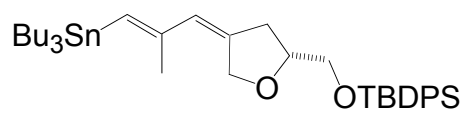

10

tert-Butyl-[4-(2-methyl-3-tributylstannanyl-allylidene)-tetrahydro-furan-2ylmethoxy]-diphenyl-silane (10)

To a $\mathrm{SnCl}_{2}(1.88 \mathrm{~g}, 9.90 \mathrm{mmol})$ suspension in $\mathrm{THF}(25 \mathrm{~mL})$ at $0{ }^{\circ} \mathrm{C}$ was added $\mathrm{nBuLi}$ (12.8 mL, $28.8 \mathrm{mmol}, 2.25 \mathrm{M}$ in hexanes) dropwise. The mixture was stirred for $20 \mathrm{~min}$ before MeMgI (7.20 mL, $9.10 \mathrm{mmol}, 1.26 \mathrm{M}$ in Ether) was added. The reaction mixture was stirred for $15 \mathrm{~min}$ before $\mathrm{CuCN}(0.200 \mathrm{~g}, 2.20 \mathrm{mmol})$ was added. To the reaction mixture was added a solution of $9(0.840 \mathrm{~g}, 2.20 \mathrm{mmol})$ in THF $(15 \mathrm{~mL})$ slowly. The reaction mixture was kept on stirring for $20 \mathrm{~min}$ before MeI $(2.7 \mathrm{~mL}, 44.0 \mathrm{mmol})$ was added. The reaction mixture was allowed to warm to r.t. in 10 min and Hexanes $(100 \mathrm{~mL})$ was added into the violently stirred reaction mixture and then the solution was decanted. The reaction flask was rinsed with Hexanes $(2 \mathrm{X} 50 \mathrm{~mL})$ and the combined organic solution was washed with brine $(40 \mathrm{~mL})$, dried, filtered and concentrated in vacuo. The product was purified by column chromatography to afford $1.17 \mathrm{~g}(78 \%)$ of $\mathbf{1 0}$ as colorless oil. (Note: $\mathbf{1 0}$ is readily hydrolyzed on a regular silica gel column. To successfully purify the compound, the silica gel column had to be saturated with $\mathrm{NEt}_{3}$ by flashing the column with a solvent mixture of $1: 20 \mathrm{NEt}_{3}$ and Hexanes and followed by flashing the column with pure Hexanes to reduce the polarity of the solvent left in the column. 10 was loaded onto the column and the column was flashed with pure Hexanes to remove the tin byproduct and then was flashed with 1:20 $\mathrm{NEt}_{3}$, Hexanes solvent 
mixture to get the purified compound 10.) $\mathrm{R}_{f} 0.38$ (EtOAc: hexanes $=1: 20$ ); IR 3071, 3049, 2955, 2927, 2856 $\mathrm{cm}^{-1}$; ${ }^{1} \mathrm{H}$ NMR $\left(400 \mathrm{MHz}, \mathrm{CDCl}_{3}\right) \delta_{\mathrm{H}} 7.67$ (d, $\left.4 \mathrm{H}, J=6.8 \mathrm{~Hz}\right)$, 7.43-7.35 (m, 6 H), $6.01(\mathrm{~s}, 1 \mathrm{H}), 5.56(\mathrm{~m}, 1 \mathrm{H}), 4.61(\mathrm{~d}, 1 \mathrm{H}, J=14.2 \mathrm{~Hz}), 4.51(\mathrm{~d}, 1 \mathrm{H}$, $J=14.2 \mathrm{~Hz}), 4.08(\mathrm{~m}, 1 \mathrm{H}), 3.69$ (m, $2 \mathrm{H}), 2.69$ (dd, $1 \mathrm{H}, J=15.9,6.4 \mathrm{~Hz}), 2.57$ (dd, $1 \mathrm{H}$, $J=16.6,6.8 \mathrm{~Hz}), 1.87(\mathrm{~s}, 3 \mathrm{H}), 1.53-1.45(\mathrm{~m}, 6 \mathrm{H}), 1.30(\mathrm{~m}, 6 \mathrm{H}), 1.06(\mathrm{~s}, 9 \mathrm{H}), 1.93-0.86$ $(\mathrm{m}, 15 \mathrm{H}) ;{ }^{13} \mathrm{C}$ NMR $\left(100 \mathrm{MHz}, \mathrm{CDCl}_{3}\right), \delta_{\mathrm{C}} 150.35,139.16,135.66,133.62,129.74$, 129.66, 129.63, 127.68, 125.99, 78.05, 69.77, 66.07, 36.77, 29.24, 27.32, 26.84, 24.65, 19.28, 13.73, 10.21; ${ }^{119} \mathrm{Sn} \mathrm{NMR}\left(149 \mathrm{MHz}, \mathrm{CDCl}_{3}\right)-56.7$;

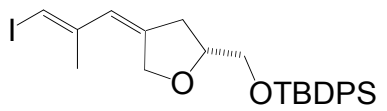

11

\section{tert-Butyl-[4-(3-iodo-2-methyl-allylidene)-tetrahydro-furan-2-ylmethoxy]-diphenyl- silane (11)}

To a solution of $10(0.980 \mathrm{~g}, 1.44 \mathrm{mmol})$ in $\mathrm{CH}_{2} \mathrm{Cl}_{2}(50 \mathrm{~mL})$ was added a solution of $\mathrm{I}_{2}$ $(0.400 \mathrm{~g}, 1.58 \mathrm{mmol})$ in $\mathrm{CH}_{2} \mathrm{Cl}_{2}(20 \mathrm{~mL})$. The reaction mixture was washed with saturated $\mathrm{Na}_{2} \mathrm{~S}_{2} \mathrm{O}_{3}$ solution $(20 \mathrm{~mL})$ and saturated $\mathrm{NH}_{4} \mathrm{~F}$ solution $(2 \mathrm{X} 20 \mathrm{~mL})$. The organic layer was washed with brine $(30 \mathrm{~mL})$, dried, filtered and concentrated in vacuo. The product was purified by column chromatography (EtOAc: hexanes $=1: 20)$ to afford $0.710 \mathrm{~g}(95 \%)$ of 11 as colorless oil. $\mathrm{R}_{f} 0.29$ (EtOAc: hexanes $\left.=1: 20\right)$; IR 3069, 3049, 2955, $2929,2857 \mathrm{~cm}^{-1} ;{ }^{1} \mathrm{H}$ NMR $\left(400 \mathrm{MHz}, \mathrm{CDCl}_{3}\right) \delta_{\mathrm{H}} 7.71-7.66(\mathrm{~m}, 4 \mathrm{H}), 7.45-7.37(\mathrm{~m}, 6 \mathrm{H})$, $6.02(\mathrm{~s}, 1 \mathrm{H}), 5.96(\mathrm{~m}, 1 \mathrm{H}, J=2.0 \mathrm{~Hz}), 4.53(\mathrm{~d}, 1 \mathrm{H}, J=14.2 \mathrm{~Hz}), 4.42(\mathrm{~d}, 1 \mathrm{H}, J=14.2$ $\mathrm{Hz}), 4.11(\mathrm{~m}, 1 \mathrm{H}), 3.71(\mathrm{~m}, 2 \mathrm{H}), 2.67(\mathrm{dd}, 1 \mathrm{H}, J=16.1,6.0 \mathrm{~Hz}), 2.55$ (dd, $1 \mathrm{H}, J=16.1$, $6.0 \mathrm{~Hz}), 1.94(\mathrm{~s}, 3 \mathrm{H}), 1.06(\mathrm{~s}, 9 \mathrm{H}) ;{ }^{13} \mathrm{C} \mathrm{NMR}\left(100 \mathrm{MHz}, \mathrm{CDCl}_{3}\right) \delta_{\mathrm{C}}$ 144.71, 141.47, $135.66,133.56,129.74,127.73,121.58,80.68,78.17,69.71,66.00,36.64,26.87,24.08$, 19.31

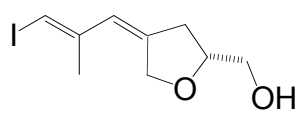

\section{S-2}

\section{[4-(3-Iodo-2-methyl-allylidene)-tetrahydro-furan-2-yl]-methanol (S-2)}

To a solution of $11(0.680 \mathrm{~g}, 1.31 \mathrm{mmol})$ in THF $(20 \mathrm{~mL})$ at $0{ }^{\circ} \mathrm{C}$ was added a TBAF solution (1.44 $\mathrm{mL}, 1.44 \mathrm{mmol}, 1 \mathrm{M}$ in $\mathrm{THF})$. The reaction mixture was allowed to warm to r.t. and was stirred for $3 \mathrm{~h}$. Water $(30 \mathrm{~mL})$ and EtOAc $(50 \mathrm{~mL})$ was then added to the reaction mixture and the two layers were separated. The aqueous layer was washed with EtOAc $(2 \times 30 \mathrm{~mL})$ and the combined organic layers were washed with brine $(30 \mathrm{~mL})$, dried, filtered and concentrated in vacuo. The product was purified by column chromatography (EtOAc: hexanes $=1: 1)$ to afford $0.312 \mathrm{~g}(85 \%)$ of $\mathbf{S - 2}$ as a white solid, mp.: 79.0-80.4 ${ }^{\circ} \mathrm{C} ; \mathrm{R}_{f}$ 0.20 (EtOAc: hexanes =1:2); IR 3413, 3046, 2940, 2917, 2869 $\mathrm{cm}^{-1}$; 
${ }^{1} \mathrm{H}$ NMR $\left(500 \mathrm{MHz}, \mathrm{CDCl}_{3}\right) \delta_{\mathrm{H}} 5.98(\mathrm{~s}, 1 \mathrm{H}), 5.92(\mathrm{~s}, 1 \mathrm{H}), 4.50(\mathrm{~d}, 1 \mathrm{H}, J=14.2 \mathrm{~Hz})$, $4.35(\mathrm{~d}, 1 \mathrm{H}, J=14.2 \mathrm{~Hz}), 4.00(\mathrm{~m}, 1 \mathrm{H}), 3.65(\mathrm{dd}, 1 \mathrm{H}, J=11.8,3.2 \mathrm{~Hz}), 3.51(\mathrm{dd}, 1 \mathrm{H}$, $J=11.8,5.8 \mathrm{~Hz}), 2.84(\mathrm{~s}, 1 \mathrm{H}), .2 .53(\mathrm{dd}, 1 \mathrm{H}, J=16.1,6.4 \mathrm{~Hz}), 2.41$ (dd, $1 \mathrm{H}, J=16.0$, $8.2 \mathrm{~Hz}), 1.88(\mathrm{~s}, 3 \mathrm{H}) ;{ }^{13} \mathrm{C} \mathrm{NMR}\left(125 \mathrm{MHz}, \mathrm{CDCl}_{3}\right) \delta_{\mathrm{C}} 144.42,140.56,122.02,81.08$, 78.46, 69.38, 63.76, 35.55, 24.00; HRMS calcd for $\mathrm{C}_{9} \mathrm{H}_{13} \mathrm{IO}_{2}(\mathrm{M})^{+}$279.9960, found: 279.9955 .

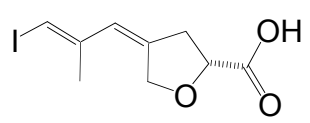

12

\section{4-(3-Iodo-2-methyl-allylidene)-tetrahydro-furan-2-carboxylic acid (12)}

To a solution of $(\mathrm{COCl})_{2}\left(0.47 \mathrm{~mL}, 0.94 \mathrm{mmol}, 2 \mathrm{M}\right.$ solution in $\left.\mathrm{CH}_{2} \mathrm{Cl}_{2}\right)$ in $\mathrm{CH}_{2} \mathrm{Cl}_{2}(3.5$ $\mathrm{mL})$ at $-60{ }^{\circ} \mathrm{C}$ was added a solution of DMSO (0.146) in $\mathrm{CH}_{2} \mathrm{Cl}_{2}(1 \mathrm{~mL})$. The reaction mixture was stirred for $2 \mathrm{~min}$ and a solution of $\mathbf{S - 2}(0.238 \mathrm{~g}, 0.85 \mathrm{mmol})$ in $\mathrm{CH}_{2} \mathrm{Cl}_{2}(2$ $\mathrm{mL}$ ) was added slowly within $5 \mathrm{~min}$. The stirring was continued for an addition $15 \mathrm{~min}$ before $\mathrm{NEt}_{3}(0.6 \mathrm{~mL}, 4.25 \mathrm{mmol})$ was added. The reaction mixture was stirred for $5 \mathrm{~min}$ and then was allowed to warm to r.t. The reaction mixture was concentrated and then was taken by EtOH $(1.5 \mathrm{ml})$. To this mixture at $0{ }^{\circ} \mathrm{C}$ was slowly added an aqueous solution of $\mathrm{AgNO}_{3}(0.860 \mathrm{~g}, 5.06 \mathrm{mmol}$ in $3.4 \mathrm{~mL}$ water) followed by an aqueous solution of $\mathrm{KOH}$ $(0.423 \mathrm{~g}, 7.6 \mathrm{mmol}$ in $1.8 \mathrm{~mL}$ water). The reaction mixture was stirred for $15 \mathrm{~h}$ and then was filtered through a pad of Celite. The reaction flask and the Celite were rinsed with water $(2 \mathrm{X} 20 \mathrm{~mL})$. The combined filtrates were acidified at $0{ }^{\circ} \mathrm{C}$ with $2 \mathrm{~N} \mathrm{HCl}$ aqueous solution till $\mathrm{PH}$ got to 2 . The aqueous solution was extracted with ether ( $5 \mathrm{X} 30 \mathrm{~mL})$. The combined organic layers were dried, filtered and concentrated in vacuo to afford $0.215 \mathrm{~g}$ (86\%) of 12 as a white solid, mp.: 83.4-86.2 ${ }^{\circ} \mathrm{C}$; $\mathrm{R}_{f} 0.30\left(\mathrm{MeOH}: \mathrm{CH}_{2} \mathrm{Cl}_{2}=1: 50\right)$; IR 3050, 2961, 2923, 1710 $\mathrm{cm}^{-1} ;{ }^{1} \mathrm{H}$ NMR $\left(400 \mathrm{MHz}, \mathrm{CDCl}_{3}\right) \delta_{\mathrm{H}} 9.18(\mathrm{~s}, 1 \mathrm{H}), 6.08(\mathrm{~s}, 1 \mathrm{H}), 6.00(\mathrm{~s}$, $1 \mathrm{H}), 4.66$ (d, $1 \mathrm{H}, J=14.0 \mathrm{~Hz}), 4.60-4.52$ (m, $2 \mathrm{H}), 3.01$ (dd, $1 \mathrm{H}, J=16.2,8.4 \mathrm{~Hz}), 2.78$ (dd, $1 \mathrm{H}, J=16.2,4.3 \mathrm{~Hz}), 1.93(\mathrm{~s}, 3 \mathrm{H}) ;{ }^{13} \mathrm{C} \mathrm{NMR}\left(100 \mathrm{MHz}, \mathrm{CDCl}_{3}\right) \delta_{\mathrm{C}} 176.94,144.24$, 137.31, 123.09, 82.11, 75.20, 69.90, 37.77, 23.87; HRMS calcd for $\mathrm{C}_{9} \mathrm{H}_{11} \mathrm{IO}_{3}(\mathrm{M})^{+}$ 293.9753, found: 293.9747.

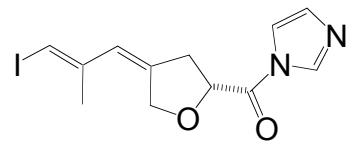

13

Imidazol-1-yl-[4-(3-iodo-2-methyl-allylidene)-tetrahydro-furan-2-yl]-methanone (13)

To a solution of $12(0.392 \mathrm{~g}, 1.34 \mathrm{mmol})$ in THF $(5 \mathrm{~mL})$ was added CDI $(0.260 \mathrm{~g}, 1.60$ mmol). The reaction mixture was stirred for $2 \mathrm{~h}$ before water $(20 \mathrm{~mL})$ and $\mathrm{CH}_{2} \mathrm{Cl}_{2}(40$ $\mathrm{mL}$ ) was added. The two layers were separated and the aqueous layer was washed with 
$\mathrm{CH}_{2} \mathrm{Cl}_{2}(2 \mathrm{X} 20 \mathrm{~mL})$. The combined organic layers were dried, filtered and concentrated in vacuo to afford $0.434 \mathrm{~g}(95 \%)$ of $\mathbf{1 3}$ as a white solid; m. p.: $101.0-105.0{ }^{\circ} \mathrm{C} ; \mathrm{R}_{f} 0.28$ (MeOH: $\mathrm{CH}_{2} \mathrm{Cl}_{2}=1: 50$ ); IR 3158, 3131, 3057, 2964, 2922, 2850, 2360, 2341, 1731, $1568 \mathrm{~cm}^{-1} ;{ }^{1} \mathrm{H}$ NMR $\left(400 \mathrm{MHz}, \mathrm{CDCl}_{3}\right) \delta_{\mathrm{H}} 8.27(\mathrm{~s}, 1 \mathrm{H}), 7.50(\mathrm{~s}, 1 \mathrm{H}), 7.02(\mathrm{~s}, 1 \mathrm{H}), 6.05$ (s, $1 \mathrm{H}), 6.00(\mathrm{~s}, 1 \mathrm{H}), 5.00(\mathrm{~m}, 1 \mathrm{H}), 4.56(\mathrm{~s}, 2 \mathrm{H}), 3.03(\mathrm{dd}, 1 \mathrm{H}, J=16.2,3.3 \mathrm{~Hz}), 2.95$ $(\mathrm{dd}, 1 \mathrm{H}, J=15.6,7.4 \mathrm{~Hz}), 1.88(\mathrm{~s}, 3 \mathrm{H}) ;{ }^{13} \mathrm{C} \mathrm{NMR}\left(100 \mathrm{MHz}, \mathrm{CDCl}_{3}\right) \delta_{\mathrm{C}} 168.09,144.12$, 137.10, 136.72, 130.83, 123.46, 116.45, 82.45, 76.61, 70.10, 36.48, 23.87.

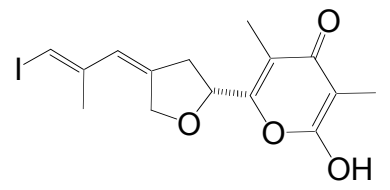

S-3

\section{2-Hydroxy-6-[4-(3-iodo-2-methyl-allylidene)-tetrahydro-furan-2-yl]-3,5-dimethyl- pyran-4-one (S-3)}

To a suspension of $\mathrm{NaH}(0.100 \mathrm{~g}, 2.44 \mathrm{mmol}, 60 \%$ in mineral oil) in THF $(6 \mathrm{~mL})$ was added a solution of $\mathbf{1 4}(0.352 \mathrm{~g}, 2.44 \mathrm{mmol})$ in THF $(8 \mathrm{~mL})$ dropwise at $0{ }^{\circ} \mathrm{C}$. After 10 $\mathrm{min}$, the reaction mixture was cooled to $-78^{\circ} \mathrm{C}$, and $\mathrm{n}-\mathrm{BuLi}(1.12 \mathrm{~mL}, 2.44 \mathrm{mmol}, 2.19$ $\mathrm{M}$ in hexanes) was added dropwise. The reaction mixture was stirred for $10 \mathrm{~min}$ before warm to $-10^{\circ} \mathrm{C}$, at which it is stirred for another $10 \mathrm{~min}$. Then the reaction mixture was cooled back to $-78^{\circ} \mathrm{C}$ and a solution of $\mathbf{1 3}(0.420 \mathrm{mg}, 1.22 \mathrm{mmol})$ in THF $(6 \mathrm{~mL})$ was added. The reaction mixture was stirred for $2 \mathrm{~h}$ before it is warmed to $-23{ }^{\circ} \mathrm{C}$ and stirred for an additional $2 \mathrm{~h}$ at this temperature. The reaction was quenched by $1 \mathrm{~N} \mathrm{HCl}$ aqueous solution.$(5 \mathrm{~mL})$ and diluted with EtOAc $(40 \mathrm{~mL})$. The two layers were separated and the aqueous layer was washed with EtOAc $(2 \mathrm{X} 30 \mathrm{~mL})$. The combined organic layers were washed with brine $(30 \mathrm{~mL})$, dried, filtered and concentrated in vacuo. The product was purified by column chromatography (EtOAc: hexanes $=1: 4$ ) to afford yellow oil $(0.418 \mathrm{~g}$ ), which is used in the next step without fully characterization. A mixture of this material and DBU $(0.228 \mathrm{~g}, 1.5 \mathrm{mmol})$ in benzene $(10 \mathrm{~mL})$ was heated at $90{ }^{\circ} \mathrm{C}$ for $3 \mathrm{~h}$. The reaction mixture was cooled to r.t. and acidified with $1 \mathrm{~N} \mathrm{HCl}$ aqueous solution $(2 \mathrm{~mL})$ and diluted with water $(10 \mathrm{~mL})$ and $\operatorname{EtOAc}(15 \mathrm{~mL})$. The two layers were separated and the aqueous layers were washed with EtOAc $(2 \mathrm{X} \mathrm{mL})$. The combined organic layers were dried, filtered and concentrated in vacuo. The product was purified by column chromatography (pure EtOAc) to afford $0.213 \mathrm{~g}(45 \%)$ of $\mathbf{S - 3}$ as a white solid. m.p.: decomp. at $140{ }^{\circ} \mathrm{C}$;. $\mathrm{R}_{f} 0.26\left(\mathrm{MeOH}: \mathrm{CH}_{2} \mathrm{Cl}_{2}=1: 20\right)$; IR 3240 (br), 2929, 2360, 1669, $1569 \mathrm{~cm}^{-1} ;{ }^{1} \mathrm{H}$ NMR $\left(400 \mathrm{MHz}, \mathrm{CDCl}_{3}\right) \delta_{\mathrm{H}} 7.67(\mathrm{~s}, 1 \mathrm{H}), 6.05(\mathrm{~s}, 1 \mathrm{H}), 5.99(\mathrm{~s}, 1 \mathrm{H}), 4.96$ (t, $1 \mathrm{H}, J=7.4 \mathrm{~Hz}), 4.67$ (d, $1 \mathrm{H}, J=13.8 \mathrm{~Hz}), 4.25(\mathrm{~d}, 1 \mathrm{H}, J=13.8 \mathrm{~Hz}), 2.95(\mathrm{dd}, 1 \mathrm{H}, J$ $=16.0,7.4 \mathrm{~Hz}), 2.76(\mathrm{dd}, 1 \mathrm{H}, J=16.0,7.0 \mathrm{~Hz}), 2.04(\mathrm{~s}, 3 \mathrm{H}), 1.98(\mathrm{~s}, 3 \mathrm{H}), 1.93(\mathrm{~s}, 3 \mathrm{H})$; ${ }^{13} \mathrm{C}$ NMR $\left(100 \mathrm{MHz}, \mathrm{CDCl}_{3}\right) \delta_{\mathrm{C}} 165.36,164.38,154.34,144.42,139.41,122.37,109.64$, $100.35,81.51,73.35,69.92,37.37,23.97,9.36,8.74$; HRMS calcd for $\mathrm{C}_{15} \mathrm{H}_{17} \mathrm{IO}_{4}(\mathrm{M})^{+}$ 388.0172, found: 388.0167 


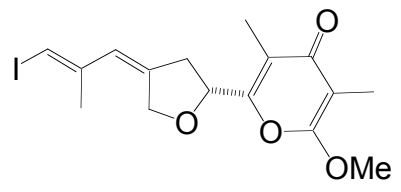

15

\section{2-[4-(3-Iodo-2-methyl-allylidene)-tetrahydro-furan-2-yl]-6-methoxy-3,5-dimethyl- pyran-4-one (15)}

To a solution of $\mathbf{S - 3}(0.200 \mathrm{~g}, 0.52 \mathrm{mmol})$ in $\mathrm{CH}_{2} \mathrm{Cl}_{2}(5 \mathrm{~mL})$ was added $\mathrm{MeOSO}_{2} \mathrm{~F}(0.588$ $\mathrm{g}, 5.2 \mathrm{mmol})$ dropwise. After $4 \mathrm{~h}$, the reaction mixture was concentrated and taken by $\mathrm{CH}_{2} \mathrm{Cl}_{2}(20 \mathrm{~mL})$. The organic solution was washed by $1 \mathrm{~N} \mathrm{NaOH}$ aqueous solution, dried, filtered and concentrated in vacuo. The product was purified by column chromatography $\left(1: 1=\right.$ EtOAc: Hexanes) to afford $0.136 \mathrm{~g}(65 \%)$ of $\mathbf{1 5}$ as a yellowish solid; $\mathrm{R}_{f} 0.25$ (EtOAc: Hexanes = 1:1); IR 2955, 2923, 1665, 1597 $\mathrm{cm}^{-1} ;{ }^{1} \mathrm{H} \mathrm{NMR}\left(400 \mathrm{MHz}, \mathrm{CDCl}_{3}\right) \delta_{\mathrm{H}}$ $6.11(\mathrm{~s}, 1 \mathrm{H}), 6.06(\mathrm{t}, 1 \mathrm{H}, J=2.0 \mathrm{~Hz}), 5.11(\mathrm{t}, 1 \mathrm{H}, J=7.0 \mathrm{~Hz}), 4.67(\mathrm{~d}, 1 \mathrm{H}, J=14.0 \mathrm{~Hz})$, $4.55(\mathrm{~d}, 1 \mathrm{H}, J=14.0 \mathrm{~Hz}), 3.89(\mathrm{~s}, 3 \mathrm{H}), 2.92(\mathrm{dd}, 1 \mathrm{H}, J=16.0,7.3 \mathrm{~Hz}), 2.80(\mathrm{dd}, 1 \mathrm{H}, J$ $=16.0,6.3 \mathrm{~Hz}), 2.00(\mathrm{~s}, 3 \mathrm{H}), 1.96(\mathrm{~s}, 3 \mathrm{H}), 1.83(\mathrm{~s}, 3 \mathrm{H}) ;{ }^{13} \mathrm{C} \mathrm{NMR}\left(100 \mathrm{MHz}, \mathrm{CDCl}_{3}\right)$ $\delta_{\mathrm{C}} 180.57,162.08,154.74,144.16,139.42,122.43,120.09,100.03,81.92,73.38,70.07$, 55.27, 37.77, 23.99, 9.44, 6.92; HRMS calcd for $\mathrm{C}_{16} \mathrm{H}_{19} \mathrm{IO}_{4}(\mathrm{M})^{+}$402.0328, found: 402.0328

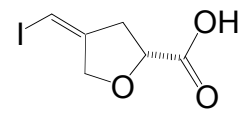

16

\section{4-Iodomethylene-tetrahydro-furan-2-carboxylic acid (16)}

Followed the same procedure as in preparation of $\mathbf{1 2 .}$

White solid, m.p. 64.0-66.2 ${ }^{\circ} \mathrm{C}$. $\mathrm{R}_{f} 0.37$ (MeOH: $\mathrm{CH}_{2} \mathrm{Cl}_{2}=1: 8$ ); IR 3069 (br), 2640, $1731 \mathrm{~cm}^{-1} ;{ }^{1} \mathrm{H}$ NMR $\left(500 \mathrm{MHz}, \mathrm{CDCl}_{3}\right) \delta_{\mathrm{H}} 11.04(\mathrm{~s}, 1 \mathrm{H}), 6.04(\mathrm{~s}, 1 \mathrm{H}), 4.76-4.73$ (m, 1 H), 4.41 (d, $1 \mathrm{H}, J=14.5 \mathrm{~Hz}), 4.29$ (d, $1 \mathrm{H}, J=14.5 \mathrm{~Hz}), 2.93$ (dd, $1 \mathrm{H}, J=16.1,8.2 \mathrm{~Hz})$, $2.76(\mathrm{dd}, 1 \mathrm{H}, J=6.0,3.5 \mathrm{~Hz}) ;{ }^{13} \mathrm{C} \mathrm{NMR}\left(125 \mathrm{MHz}, \mathrm{CDCl}_{3}\right) \delta_{\mathrm{C}} 176.87,147.76,77.84$, 75.81, 68.41, 37.81; HRMS calcd for $\mathrm{C}_{6} \mathrm{H}_{7} \mathrm{IO}_{3}(\mathrm{M})^{+}$253. 9440, found: 253.9436

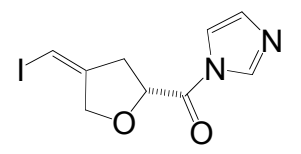

17

Imidazol-1-yl-(4-iodomethylene-tetrahydro-furan-2-yl)-methanone (17) 
Followed the same procedure as in preparation of $\mathbf{1 3 .}$

Yellowish solid, m.p.: 85.0-90.0 ${ }^{\circ} \mathrm{C} . \mathrm{R}_{f} 0.19$ (MeOH: $\mathrm{CH}_{2} \mathrm{Cl}_{2}=1$ :9); IR 3394, 3146, $2969,2842,2620,1988,1596,1415 \mathrm{~cm}^{-1} ;{ }^{1} \mathrm{H}$ NMR $\left(500 \mathrm{MHz}, \mathrm{CDCl}_{3}\right) \delta_{\mathrm{H}} 8.21(\mathrm{~s}, 1 \mathrm{H})$, $7.44(\mathrm{~s}, 1 \mathrm{H}), 6.95(\mathrm{~s}, 1 \mathrm{H}), 6.04(\mathrm{~s}, 1 \mathrm{H}), 5.16(\mathrm{t}, 1 \mathrm{H}, J=6.3 \mathrm{~Hz}), 4.29(\mathrm{~s}, 2 \mathrm{H}), 3.0(\mathrm{~d}, 1$ $\mathrm{H}, J=16.1 \mathrm{~Hz}), 2.87(\mathrm{dd}, 1 \mathrm{H}, J=16.1,7.6 \mathrm{~Hz}) ;{ }^{13} \mathrm{C} \mathrm{NMR}\left(125 \mathrm{MHz}, \mathrm{CDCl}_{3}\right) \delta_{\mathrm{C}} 167.55$, $147.28,137.02,130.70,116.39,79.27,75.99,68.78,36.42$

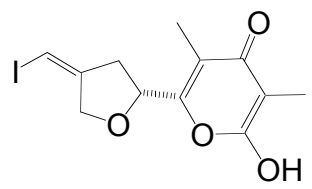

S-4

2-Hydroxy-6-(4-iodomethylene-tetrahydro-furan-2-yl)-3,5-dimethyl-pyran-4-one (S4)

Followed the same procedure as in preparation of $\mathbf{S - 3}$.

Yellowish solid, m.p.: decomp. at $160{ }^{\circ} \mathrm{C}$; $\mathrm{R}_{f} 0.20$ (EtOAc: hexanes $=1: 1$ ); IR 3072 (br), 2930, 1669, $1567 \mathrm{~cm}^{-1} ;{ }^{1} \mathrm{H}$ NMR $\left(500 \mathrm{MHz}, \mathrm{CDCl}_{3}\right) \delta_{\mathrm{H}} 8.37$ (s, $\left.1 \mathrm{H}\right), 6.04$ (s, 1 $\mathrm{H}), 5.13(\mathrm{t}, 1 \mathrm{H}, J=7.4 \mathrm{~Hz}), 4.46(\mathrm{~d}, 1 \mathrm{H}, J=14.2 \mathrm{~Hz}), 4.25$ (d, $1 \mathrm{H}, J=14.2 \mathrm{~Hz}), 2.94$ (dd, $1 \mathrm{H}, J=15.7,8.2 \mathrm{~Hz}), 2.79$ (dd, $1 \mathrm{H}, J=15.7,6.5 \mathrm{~Hz}), 2.04(\mathrm{~s}, 3 \mathrm{H}), 1.98$ (s, $3 \mathrm{H})$; ${ }^{13} \mathrm{C}$ NMR $\left(125 \mathrm{MHz}, \mathrm{CDCl}_{3}\right) \delta_{\mathrm{C}} 165.62,164.82,153.43,149.50,110.33,100.38,76.07$, $75.75,67.45,37.53,9.42,8.81$; HRMS calcd for $\mathrm{C}_{12} \mathrm{H}_{13} \mathrm{IO}_{4}(\mathrm{M})^{+} 347.9859$, found: 347.9845

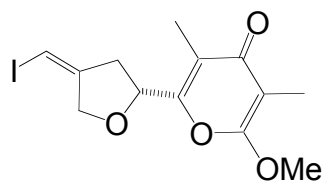

18

2-(4-Iodomethylene-tetrahydro-furan-2-yl)-6-methoxy-3,5-dimethyl-pyran-4-one (18) Followed the same procedure as in preparation of $\mathbf{1 5 .}$

White solid, m.p.: 118.0-120.5 ${ }^{\circ} \mathrm{C} \ldots \mathrm{R}_{f} 0.11$ (EtOAc: hexanes = 1:2); IR 2953, 2924, $1665,1597 \mathrm{~cm}^{-1} ;{ }^{1} \mathrm{H}$ NMR $\left(400 \mathrm{MHz}, \mathrm{CDCl}_{3}\right) \delta_{\mathrm{H}} 6.13(\mathrm{~m}, 1 \mathrm{H}, J=2.2 \mathrm{~Hz}), 5.34(\mathrm{dd}, 1 \mathrm{H}$, $J=7.4,5.7 \mathrm{~Hz}), 4.49$ (d, $1 \mathrm{H}, J=14.4 \mathrm{~Hz}), 4.36$ (d, $1 \mathrm{H}, J=14.4 \mathrm{~Hz}), 3.92(\mathrm{~s}, 3 \mathrm{H}), 2.99-$ $2.91(\mathrm{~m}, 1 \mathrm{H}), 2.80(\mathrm{dd}, 1 \mathrm{H}, J=16.0,5.1 \mathrm{~Hz}), 1.99(\mathrm{~s}, 3 \mathrm{H}), 1.82(\mathrm{~s}, 3 \mathrm{H}) ;{ }^{13} \mathrm{C} \mathrm{NMR}$ $\left(100 \mathrm{MHz}, \mathrm{CDCl}_{3}\right) \delta_{\mathrm{C}} 180.48,162.14,154.61,149.95,119.99,100.07,76.20,76.14$, 67.55, 55.50, 37.98, 9.48, 6.94; HRMS calcd for $\mathrm{C}_{13} \mathrm{H}_{15} \mathrm{IO}_{4}(\mathrm{M})^{+}$362.0015, found: 362.0013 


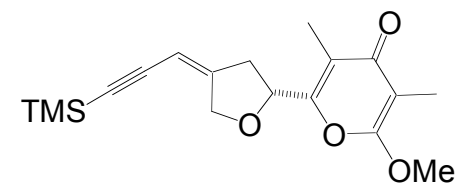

S-5

\section{2-Methoxy-3,5-dimethyl-6-[4-(3-trimethylsilanyl-prop-2-ynylidene)-tetrahydro- furan-2-yl]-pyran-4-one (S-5)}

Followed the same procedure as in preparation of $\mathbf{S - 1}$. However $\mathbf{1 8}$ is much more reactive and reaction is carried out at r.t.

Yellowish solid, m.p.: 80.0-81.8 ${ }^{\circ} \mathrm{C} . . \mathrm{R}_{f} 0.24$ (EtOAc: hexanes = 1:2); IR 2956, 2928, 1666, 1600 $\mathrm{cm}^{-1} ;{ }^{1} \mathrm{H}$ NMR $\left(400 \mathrm{MHz}, \mathrm{CDCl}_{3}\right) \delta_{\mathrm{H}} 5.56(\mathrm{~m}, 1 \mathrm{H}, J=2.4 \mathrm{~Hz}), 5.22$ (dd, $1 \mathrm{H}, J=7.6,5.5 \mathrm{~Hz}), 4.74(\mathrm{~d}, 1 \mathrm{H}, J=15.2 \mathrm{~Hz}), 4.61-4.56(\mathrm{~m}, 1 \mathrm{H}), 3.93(\mathrm{~s}, 3 \mathrm{H})$, 3.04-2.96 (m 1 H), 2.86-2.80 (m, $1 \mathrm{H}), 2.00(\mathrm{~s}, 3 \mathrm{H}), 1.83(\mathrm{~s}, 3 \mathrm{H}), 0.17(\mathrm{~s}, 9 \mathrm{H}) ;{ }^{13} \mathrm{C}$ NMR $\left(100 \mathrm{MHz}, \mathrm{CDCl}_{3}\right) \delta_{\mathrm{C}} 180.53,162.15,154.77$. 154.27, 119.88, 101.09, 100.98, 99.98, 99.94, 75.02, 71.77, 55.35, 36.21, 9.45, 6.92, -0.03; HRMS calcd for $\mathrm{C}_{18} \mathrm{H}_{24} \mathrm{O}_{4} \mathrm{Si}$ $(\mathrm{M})^{+} 332.1444$, found: 332.1448

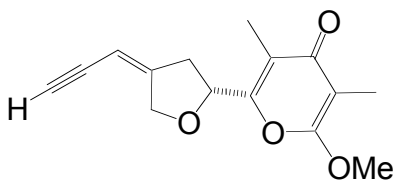

19

\section{2-Methoxy-3,5-dimethyl-6-(4-prop-2-ynylidene-tetrahydro-furan-2-yl)-pyran-4-one (19)}

To a solution of $\mathbf{S - 5}(0.065 \mathrm{~g}, 0.2 \mathrm{mmol})$ in THF $(10 \mathrm{~mL})$ at $0{ }^{\circ} \mathrm{C}$ was added a TBAF solution $(0.24 \mathrm{~mL}, 0.24 \mathrm{mmol}, 1 \mathrm{M}$ in THF). The reaction mixture was allowed to warm to r.t. and was stirred for $10 \mathrm{~min}$. Water $(10 \mathrm{~mL})$ and EtOAc $(20 \mathrm{~mL})$ was then added to the reaction mixture and the two layers were separated. The aqueous layer was washed with EtOAc ( $2 \times 10 \mathrm{~mL})$ and the combined organic layers were washed with brine $(10 \mathrm{~mL})$, dried, filtered and concentrated in vacuo. The product was purified by column chromatography (EtOAc: hexanes $=1: 1)$ to afford $0.043 \mathrm{~g}(83 \%)$ of 19 as a white solid, m.p.: 119.2-121.4 ${ }^{\circ} \mathrm{C} \ldots \mathrm{R}_{f} 0.12$ (EtOAc: hexanes = 1:2); IR 3287, 3225, 2955, 2926, $1665,1594 \mathrm{~cm}^{-1} ;{ }^{1} \mathrm{H} \mathrm{NMR}\left(500 \mathrm{MHz}, \mathrm{CDCl}_{3}\right) \delta_{\mathrm{H}} 5.54(\mathrm{~s}, 1 \mathrm{H}), 5.24(\mathrm{t}, 1 \mathrm{H}, J=6.5 \mathrm{~Hz})$, 4.75 (d, $1 \mathrm{H}, J=15.2 \mathrm{~Hz}), 4.61(\mathrm{~d}, 1 \mathrm{H}, J=15.2 \mathrm{~Hz}), 3.93(\mathrm{~s}, 3 \mathrm{H}), 3.14(\mathrm{~s}, 1 \mathrm{H}), 3.02$ (dd, $1 \mathrm{H}, J=16.2,7.2 \mathrm{~Hz}), 2.86-2.83(\mathrm{~m}, 1 \mathrm{H}), 2.00(\mathrm{~s}, 3 \mathrm{H}),, 1.83(\mathrm{~s}, 3 \mathrm{H}) ;{ }^{13} \mathrm{C} \mathrm{NMR}$ $\left(125 \mathrm{MHz}, \mathrm{CDCl}_{3}\right) \delta_{\mathrm{C}} 180.45,162.07,155.01,154.60,119.87,99.96,99.81,82.28,79.56$, 74.92, 71.63, 55.29, 36.10, 9.39, 6.85; HRMS calcd for $\mathrm{C}_{15} \mathrm{H}_{16} \mathrm{O}_{4}(\mathrm{M})^{+} 260.1049$, found: 260.1046 


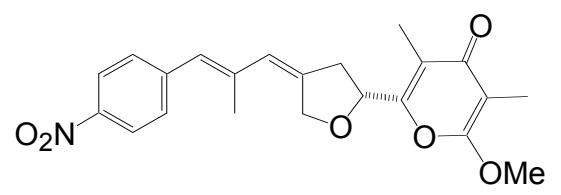

\section{Aureothin}

\section{Aureothin}

A mixture of $15(10.4 \mathrm{mg}, 0.026 \mathrm{mmol}), 21(32.0 \mathrm{mg}, 0.08 \mathrm{mmol}), \mathrm{Pd}\left(\mathrm{PPh}_{3}\right)_{4}(1.5 \mathrm{mg}$, $0.0013 \mathrm{mmol}), \mathrm{CuI}(1.0 \mathrm{mg}, 0.0052 \mathrm{mmol})$ and $\mathrm{CsF}(8.0 \mathrm{mg}, 0.052 \mathrm{mmol})$ in DMF (1 $\mathrm{mL})$ was heated at $45^{\circ} \mathrm{C}$ for $2 \mathrm{~h}$ before water $(10 \mathrm{~mL})$ was added. The mixture was extracted with EthOAc(2 X $10 \mathrm{~mL})$. The combined organic layers were washed with saturated $\mathrm{NH}_{4} \mathrm{~F}$ aqueous solution $(5 \mathrm{~mL})$ and brine $(5 \mathrm{~mL})$, dried, filtered and concentrated in in vacuo. The product was purified by column chromatography (EtOAc: hexanes $=1: 1)$ to afford $7.7 \mathrm{mg}(75 \%)$ of aureothin as a yellowish solid; $\mathrm{R}_{f} 0.17$ (EtOAc: hexanes =1:1); IR 2954, 2920, 2850, 2361, 2341, 1665, 1592, 1339 $\mathrm{cm}^{-1} ;{ }^{1} \mathrm{H}$ NMR $(500$ $\left.\mathrm{MHz}, \mathrm{CDCl}_{3}\right) \delta_{\mathrm{H}} 8.19(\mathrm{~d}, 2 \mathrm{H}, J=8.8 \mathrm{~Hz}), 7.38(\mathrm{~d}, 2 \mathrm{H}, J=8.8 \mathrm{~Hz}), 6.36(\mathrm{~s}, 1 \mathrm{H}), 6.20(\mathrm{~s}$, $1 \mathrm{H}), 5.13(\mathrm{t}, 1 \mathrm{H}, J=7.0 \mathrm{~Hz}), 4.86(\mathrm{~d}, 1 \mathrm{H}, J=14.0 \mathrm{~Hz}), 4.74(\mathrm{~d}, 1 \mathrm{H}, J=14.0 \mathrm{~Hz})$, 3.94(s, $3 \mathrm{H}), 3.05(\mathrm{dd}, 1 \mathrm{H}, J=16.0,6.8 \mathrm{~Hz}), 2.95(\mathrm{dd}, 1 \mathrm{H}, J=16.0,6.4 \mathrm{~Hz}), 2.04$ (s, 3 $\mathrm{H}), 2.03(\mathrm{~s}, 3 \mathrm{H}), 1.84(\mathrm{~s}, 3 \mathrm{H}) ;{ }^{13} \mathrm{C} \mathrm{NMR}\left(125 \mathrm{MHz}, \mathrm{CDCl}_{3}\right) \delta_{\mathrm{C}} 180.52,162.01,154.56$, $146.10,144.15,140.62,138.52,129.54,128.33,125.93,123.55,120.18,100.03,73.28$, 70.07, 55.20, 38.23, 17.69, 9.40, 6.86; HRMS calcd for $\mathrm{C}_{22} \mathrm{H}_{23} \mathrm{NO}_{6}(\mathrm{M})^{+}$397.1525, found: 397.1518

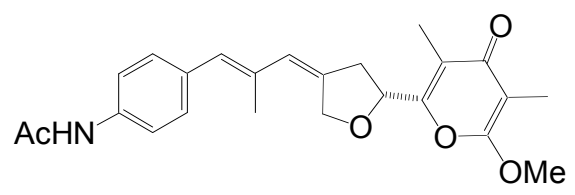

\section{$N$-Acetylaureothamine}

\section{$N$-Acetylaureothamine}

Followed the same procedure as in preparation of aureothin. $6.6 \mathrm{mg} N$ Acetylaureothamine was prepared in $65 \%$ yield from $10.0 \mathrm{mg} \mathbf{1 5}$. White solid. $\mathrm{R}_{f} 0.29$ (pure EtOAc); IR 3252, 2955, 2924, 2852, 1686, 1663, 1590 $\mathrm{cm}^{-1} ;{ }^{1} \mathrm{H}$ NMR (500 MHz, $\left.\mathrm{CDCl}_{3}\right) \delta_{\mathrm{H}} 7.48(\mathrm{~d}, 2 \mathrm{H}, J=8.4 \mathrm{~Hz}), 7.24(\mathrm{~s}, 1 \mathrm{H}), 7.21(\mathrm{~d}, 2 \mathrm{H}, J=8.4 \mathrm{~Hz}), 6.38(\mathrm{~s}, 1 \mathrm{H})$, $6.15(\mathrm{~s}, 1 \mathrm{H}), 5.13(\mathrm{dd}, 1 \mathrm{H}, J=7.3,6.3 \mathrm{~Hz}), 4.85(\mathrm{~d}, 1 \mathrm{H}, J=14.0 \mathrm{~Hz}), 4.73(\mathrm{~d}, 1 \mathrm{H}, J=$ $14.0 \mathrm{~Hz}), 3.93(\mathrm{~s}, 3 \mathrm{H}), 3.03(\mathrm{dd}, 1 \mathrm{H}, J=16.0,7.0 \mathrm{~Hz}), 2.90(\mathrm{dd}, 1 \mathrm{H}, J=16.0,6.1 \mathrm{~Hz})$, $2.18(\mathrm{~s}, 3 \mathrm{H}), 2.02(\mathrm{~s}, 3 \mathrm{H}), 2.00(\mathrm{~s}, 3 \mathrm{H}), 1.84(\mathrm{~s}, 3 \mathrm{H}) ;{ }^{13} \mathrm{C} \mathrm{NMR}\left(100 \mathrm{MHz}, \mathrm{CDCl}_{3}\right) \delta_{\mathrm{C}}$ $180.68,168.21,162.16,155.14,137.87,136.50,134.45,133.55,130.06,129.73,126.70$, 119.96, 119.53, 99.96, 73.22, 70.18, 55.29, 38.28, 24.68, 17.53, 9.47, 6.94; HRMS calcd for $\mathrm{C}_{24} \mathrm{H}_{27} \mathrm{NO}_{5}(\mathrm{M})^{+} 409.1889$, found: 409.1889 


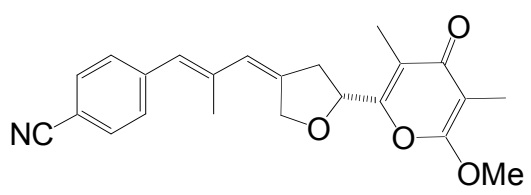

\section{Aureonitrile}

\section{Aureonitrile}

Followed the same procedure as in preparation of aureothin. $8.0 \mathrm{mg}$ aureonitrile was prepared in 74\% yield from $11.5 \mathrm{mg}$ 15. White solid; $\mathrm{R}_{f} 0.13$ (EtOAc: hexanes $=1: 1$ ); $\mathrm{R}_{f}$ 0.40 (EtOAc: hexanes = 1:2); IR 2955, 2921, 2853, 2224, 2341, 1665, 1592 $\mathrm{cm}^{-1} ;{ }^{1} \mathrm{H}$ NMR $\left(500 \mathrm{MHz}, \mathrm{CDCl}_{3}\right) \delta_{\mathrm{H}} 7.61(\mathrm{~d}, 2 \mathrm{H}, J=8.3 \mathrm{~Hz}), 7.33(\mathrm{~d}, 2 \mathrm{H}, J=8.3 \mathrm{~Hz}), 6.31(\mathrm{~s}, 1$ H), $6.17(\mathrm{~s}, 1 \mathrm{H}), 5.13(\mathrm{t}, 1 \mathrm{H}, J=7.0 \mathrm{~Hz}), 4.85(\mathrm{~d}, 1 \mathrm{H}, J=14.2 \mathrm{~Hz}), 4.72(\mathrm{~d}, 1 \mathrm{H}, J=$ $14.2 \mathrm{~Hz}), 3.93(\mathrm{~s}, 3 \mathrm{H}), 3.04(\mathrm{dd}, 1 \mathrm{H}, J=16.0,6.9 \mathrm{~Hz}), 2.80(\mathrm{dd}, 1 \mathrm{H}, J=16.0,7.3 \mathrm{~Hz})$, $2.02(\mathrm{~s}, 3 \mathrm{H}), 2.01(\mathrm{~s}, 3 \mathrm{H}), 1.84(\mathrm{~s}, 3 \mathrm{H}) ;{ }^{13} \mathrm{C} \mathrm{NMR}\left(125 \mathrm{MHz}, \mathrm{CDCl}_{3}\right) \delta_{\mathrm{C}}$ 180.54. 162.02, 154.61, 142.09, 140.19, 137.85, 131.97, 129.49, 128.69, 125.97, 120.14, 118.90, 109.99, 100.00, 73.25, 70.06, 55.19, 38.21, 17.60, 9.41, 6.87; HRMS calcd for $\mathrm{C}_{23} \mathrm{H}_{23} \mathrm{NO}_{4}(\mathrm{M})^{+}$ 377.1627, found: 377.1629

\footnotetext{
${ }^{1}$ Still, W. C.; Kahn, M.; Mitra, A. J. Org. Chem. 1978, 43, 2923-2925.

${ }^{2}$ Alaimo, P. J.; Peters, D. W.;Arnold, J.; Bergman, R. G. J. Chem. Ed. 2001, 78, 64.
} 


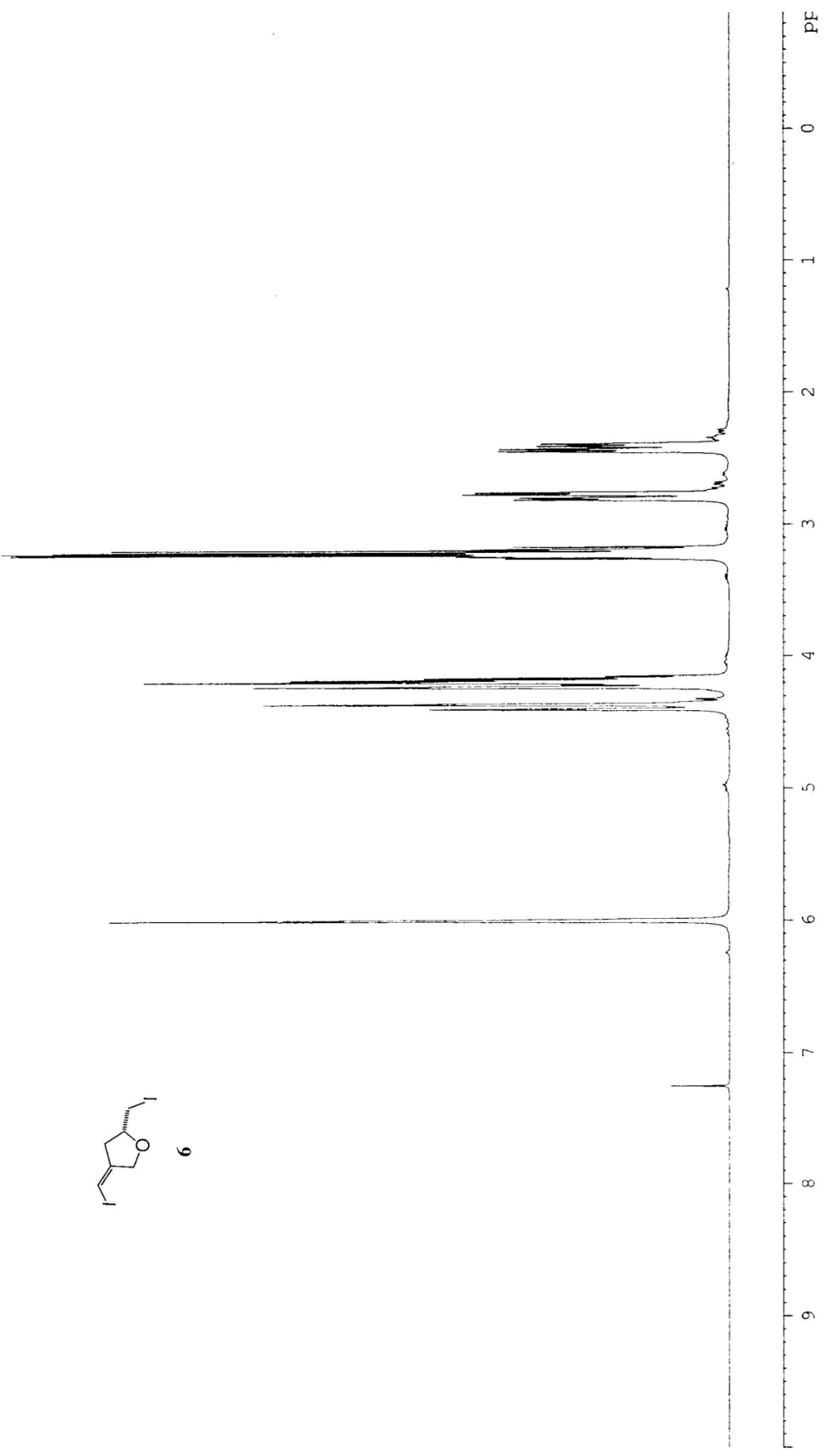

S13 


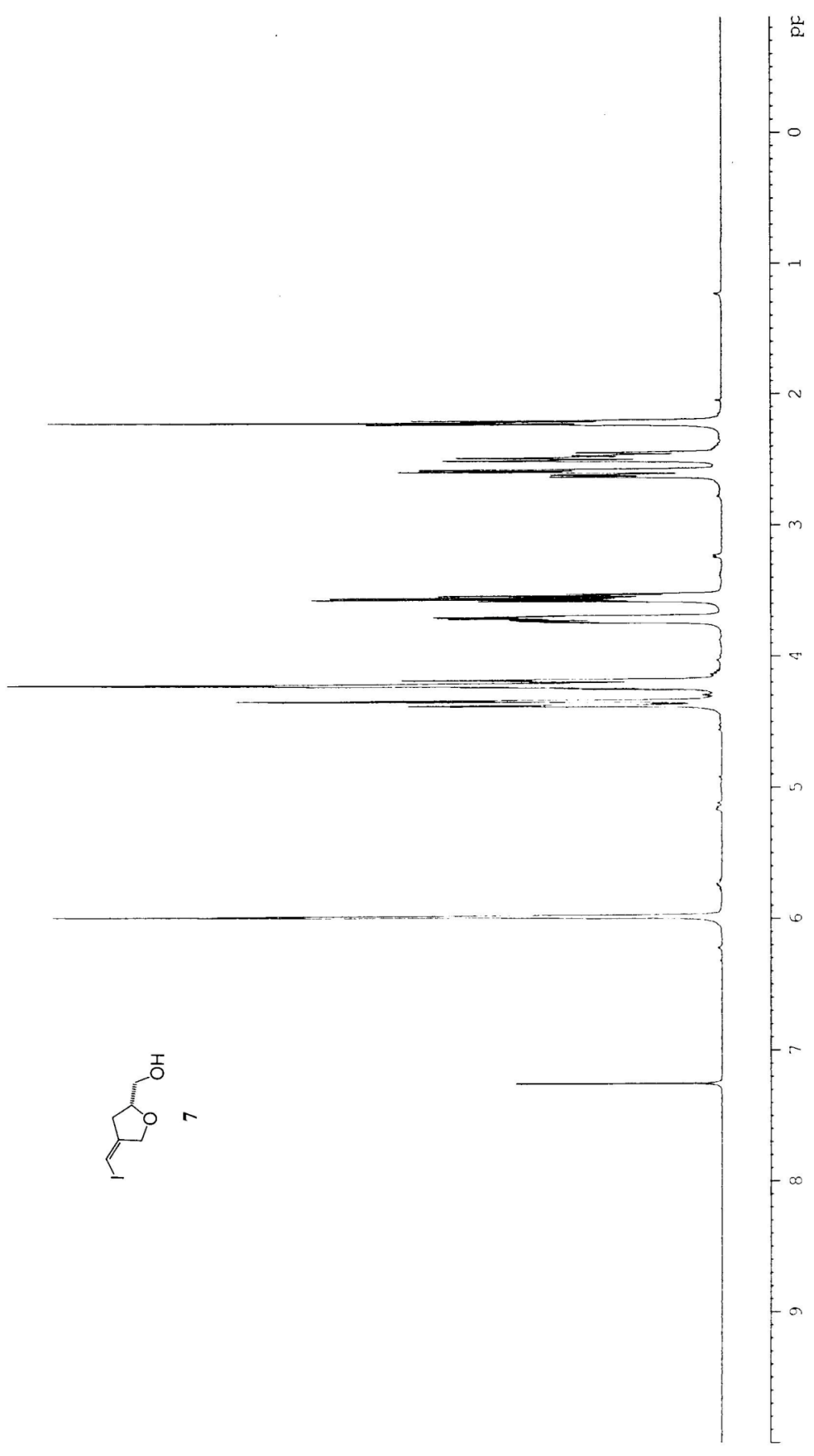




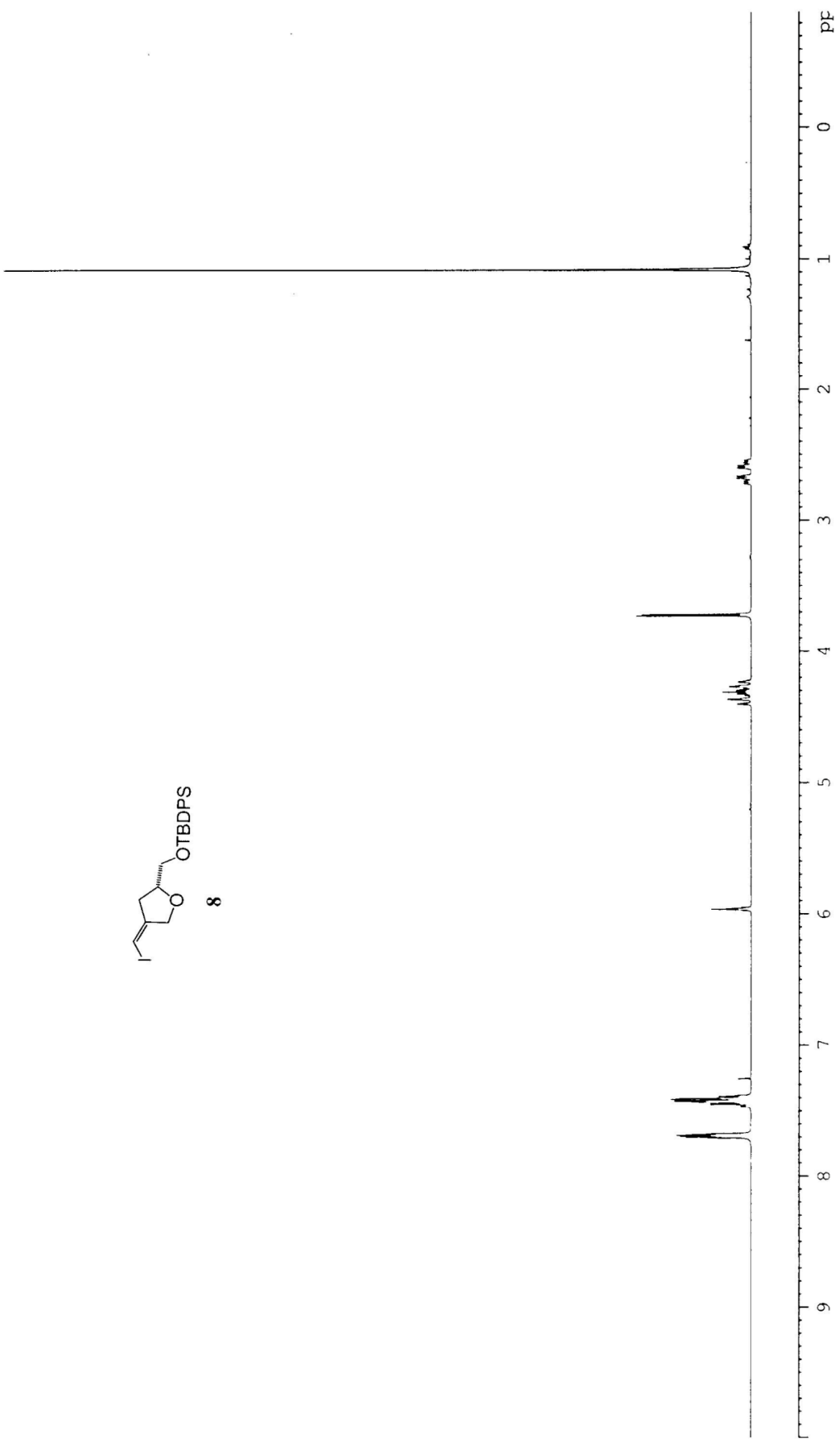

S15 


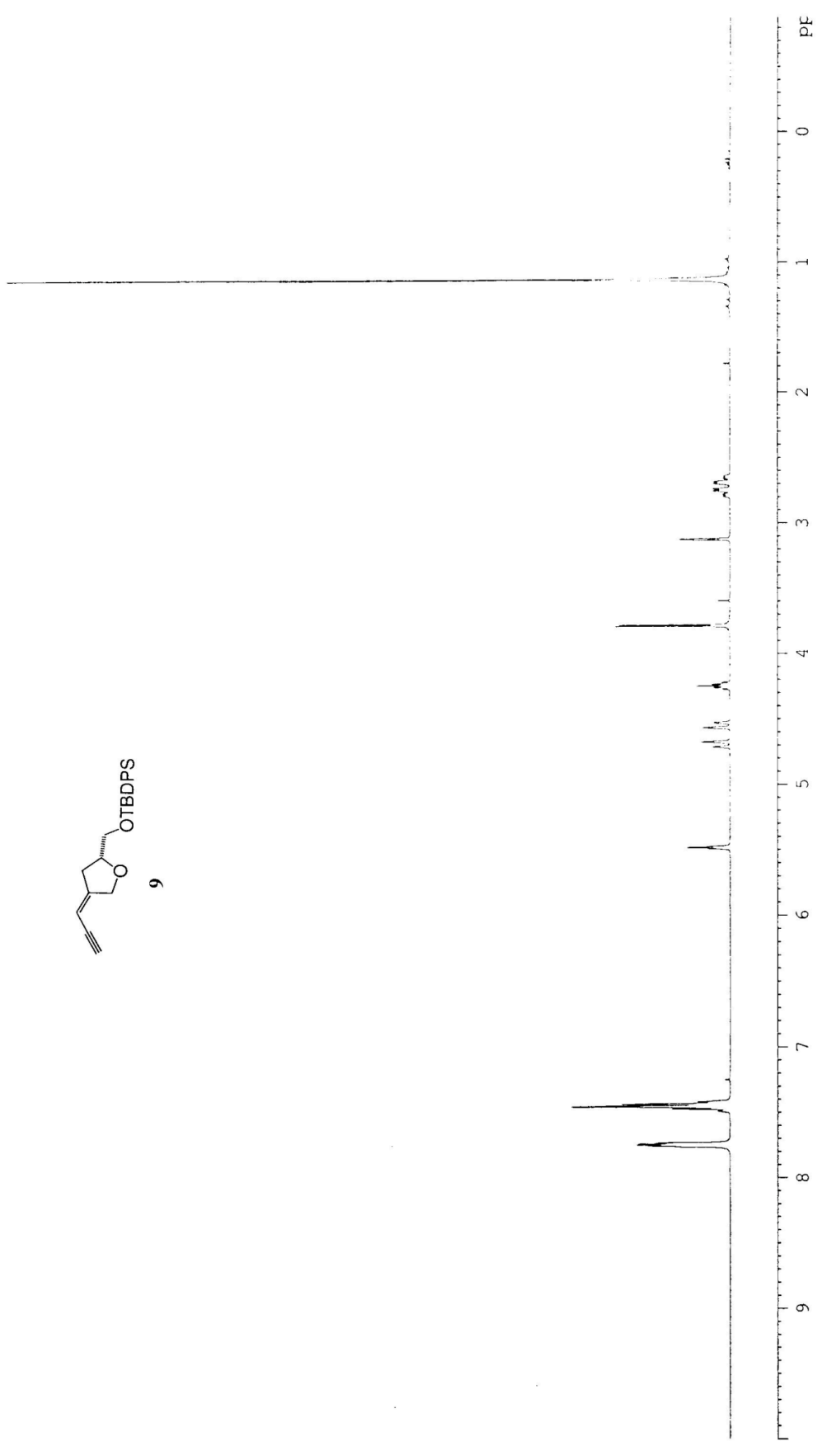

S16 


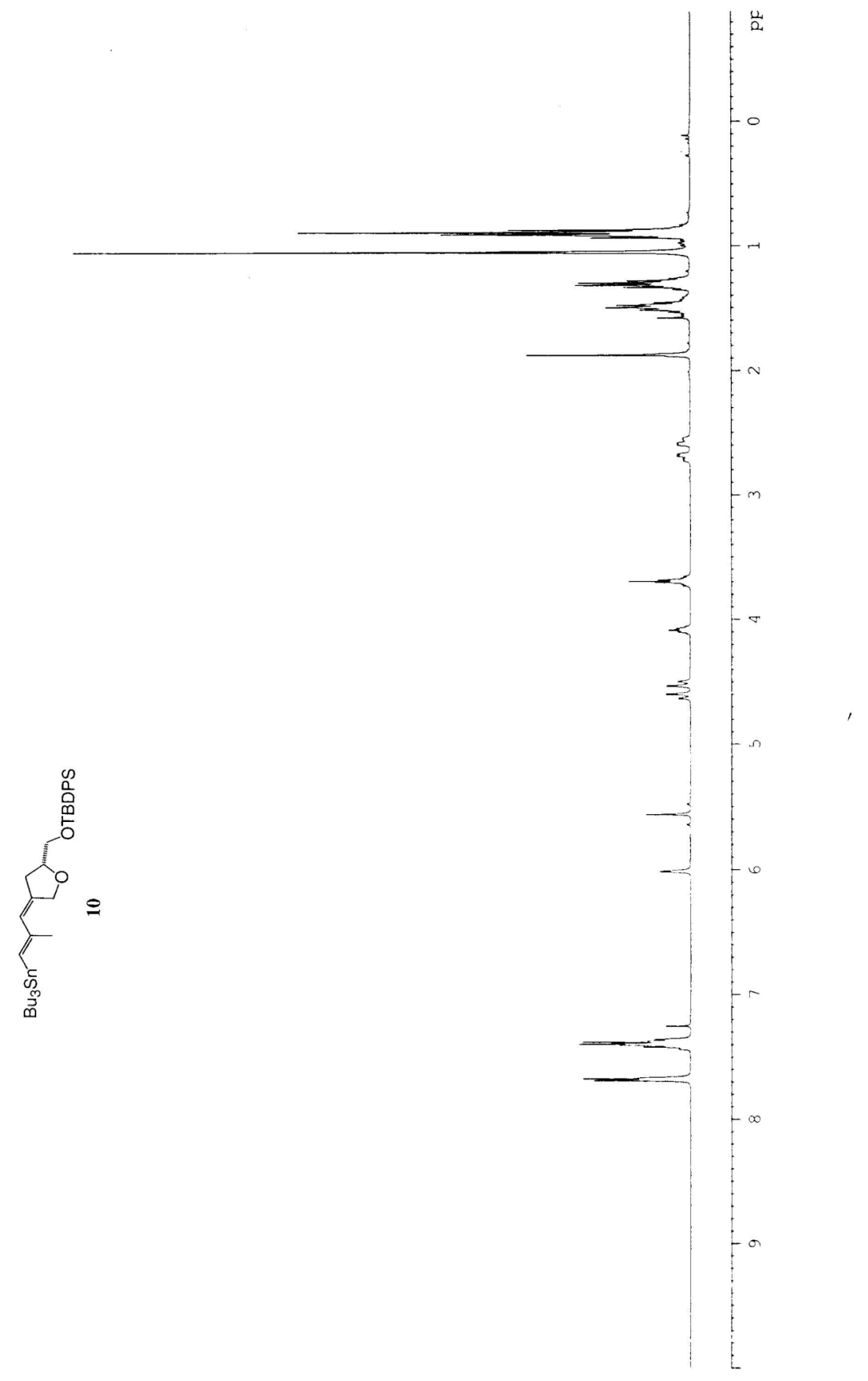

S17 


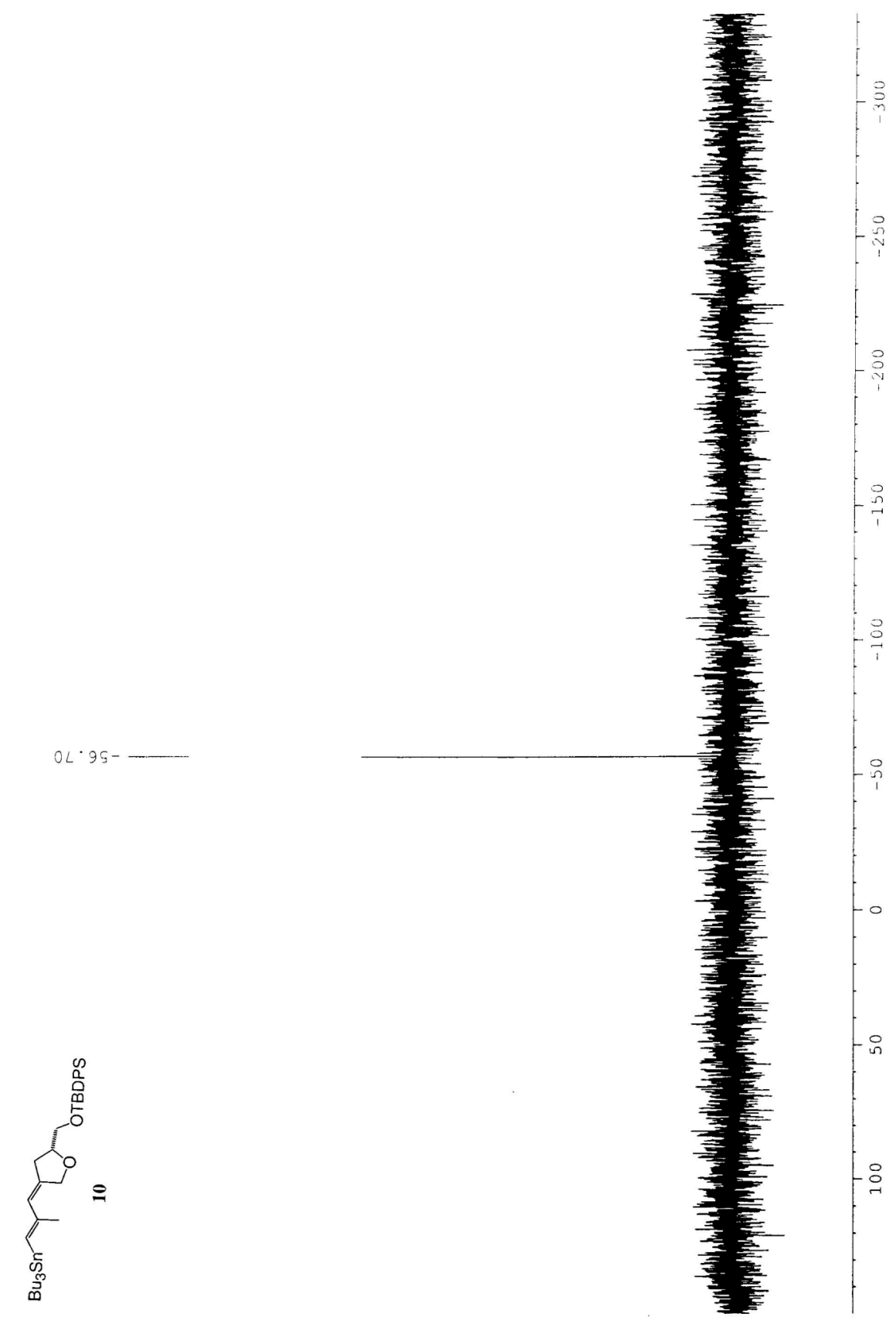




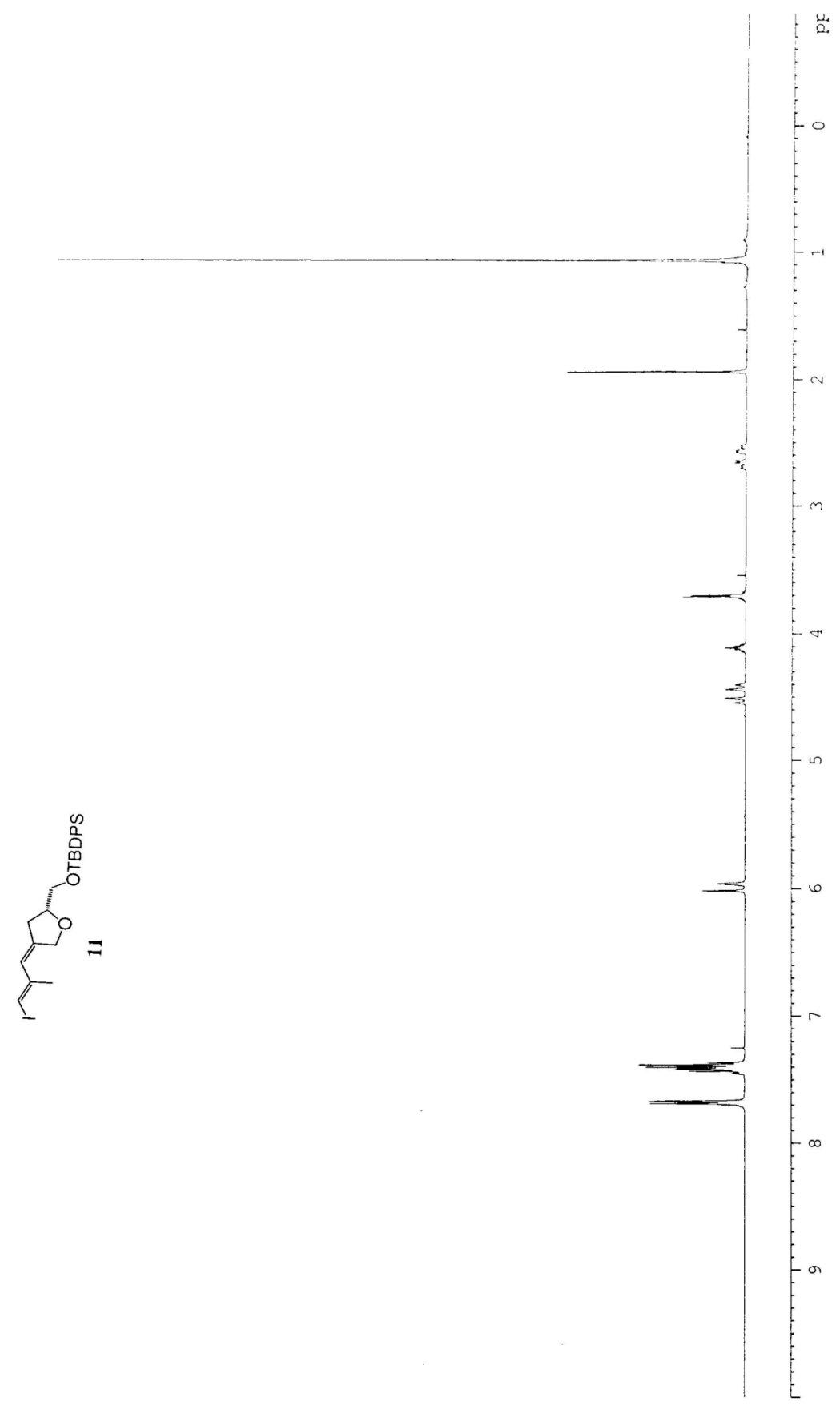




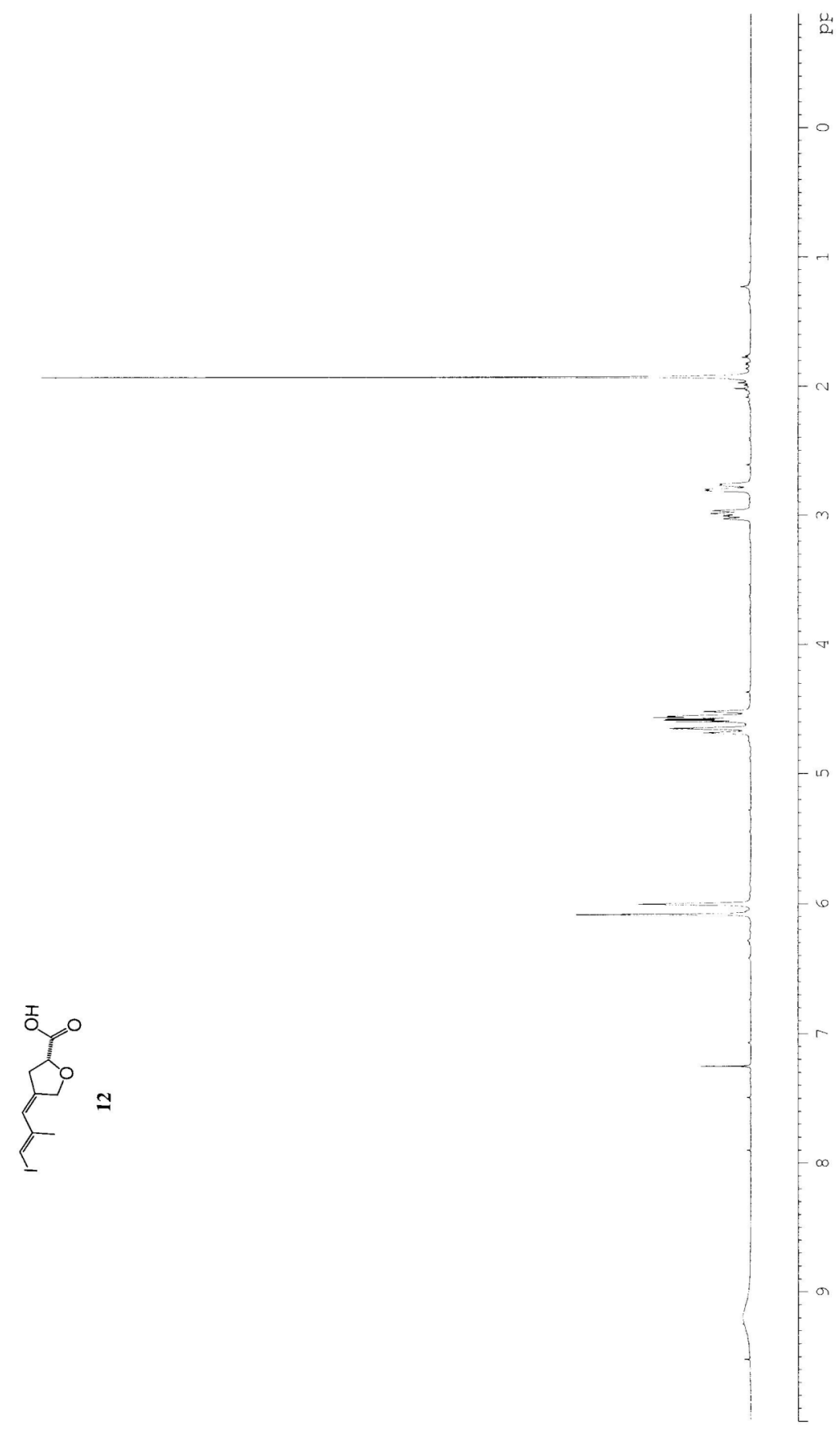




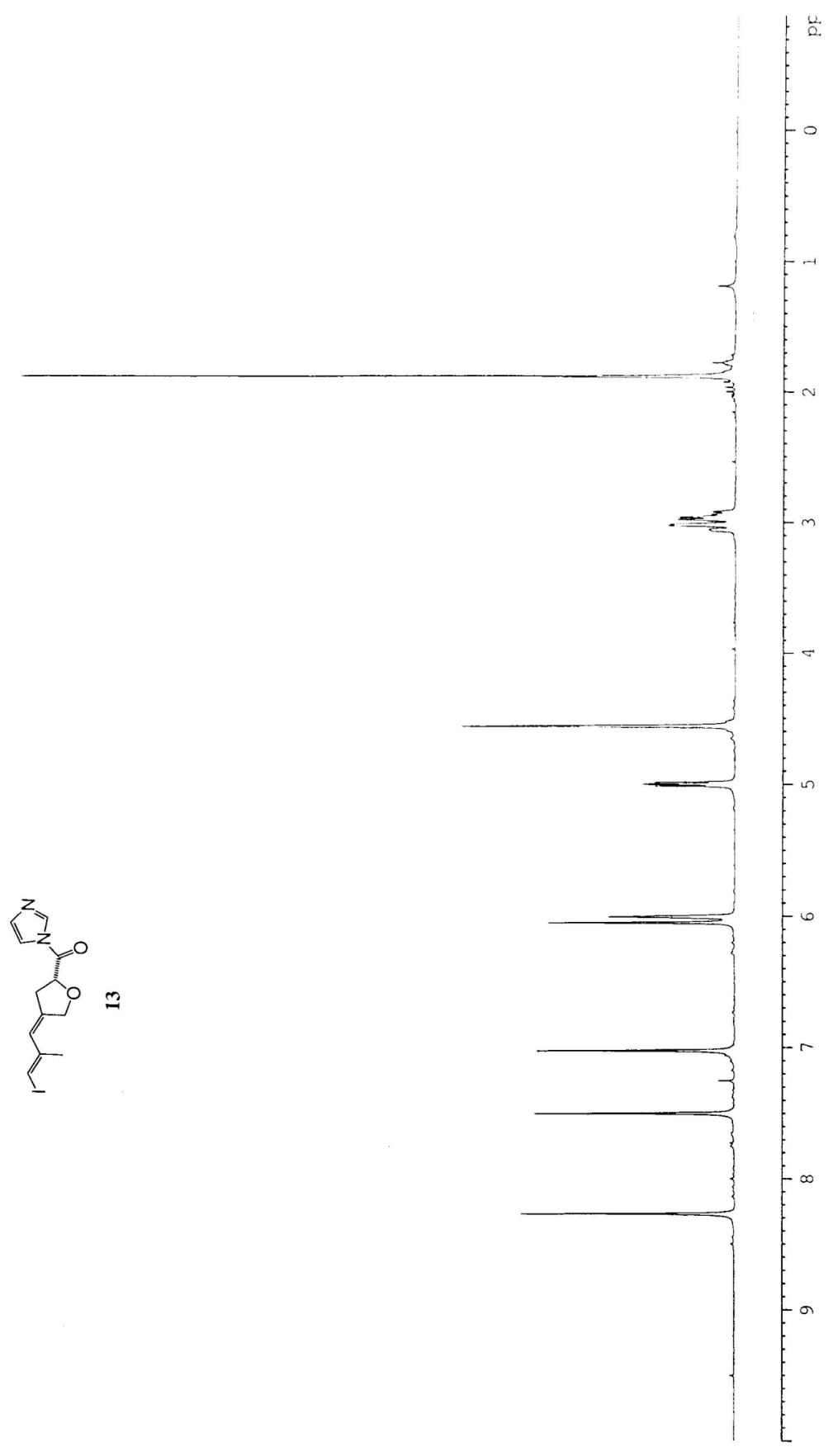









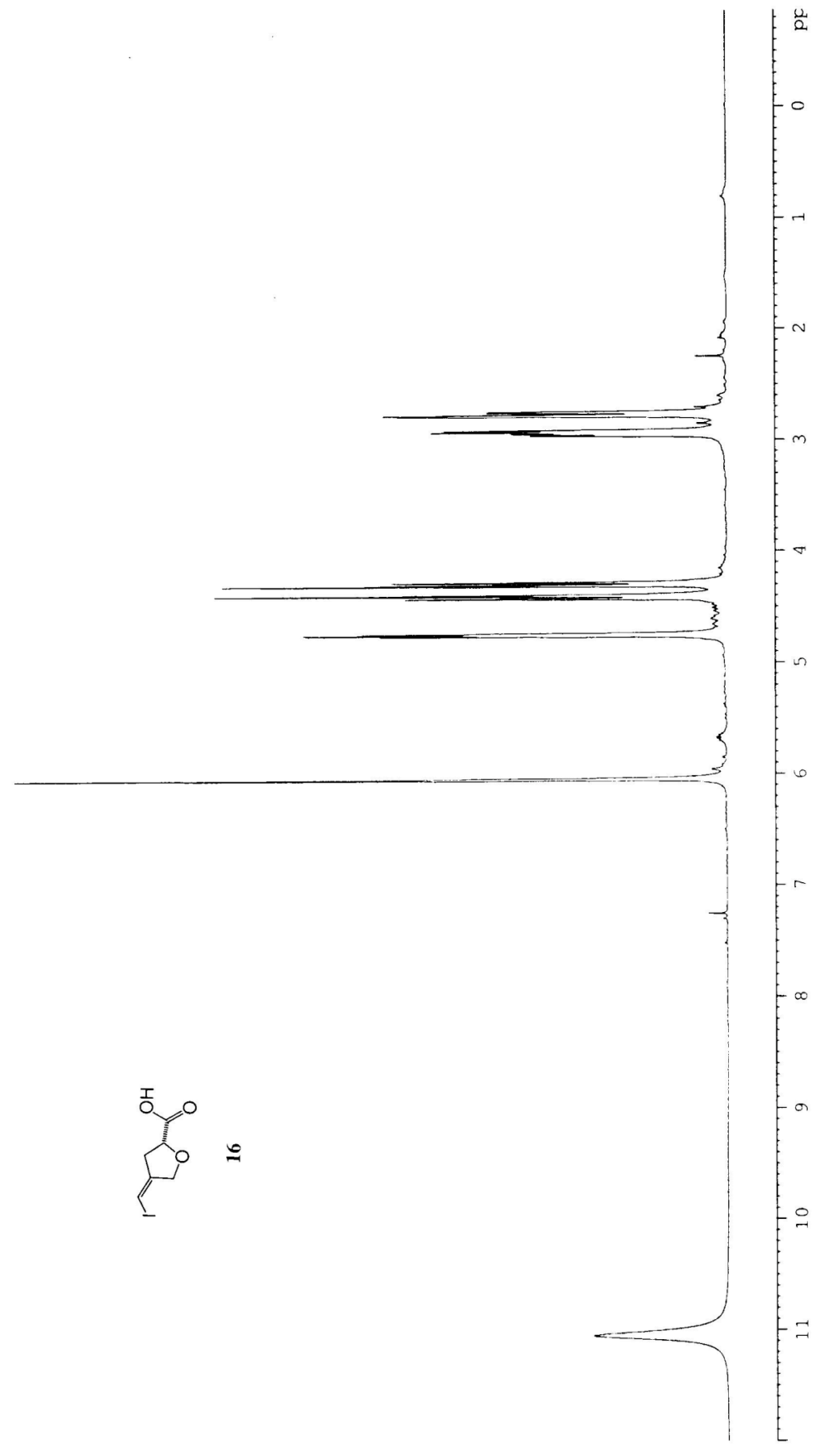




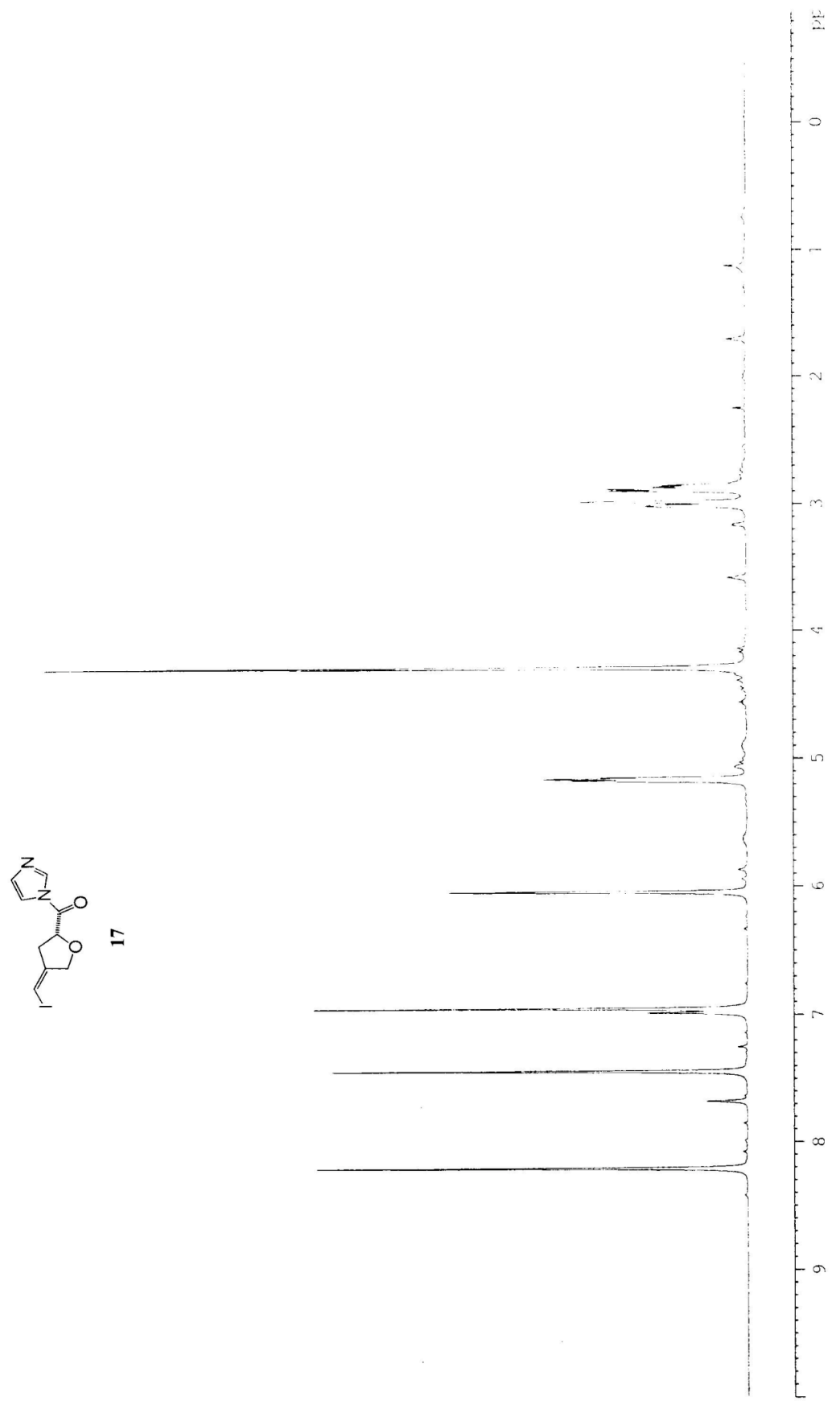




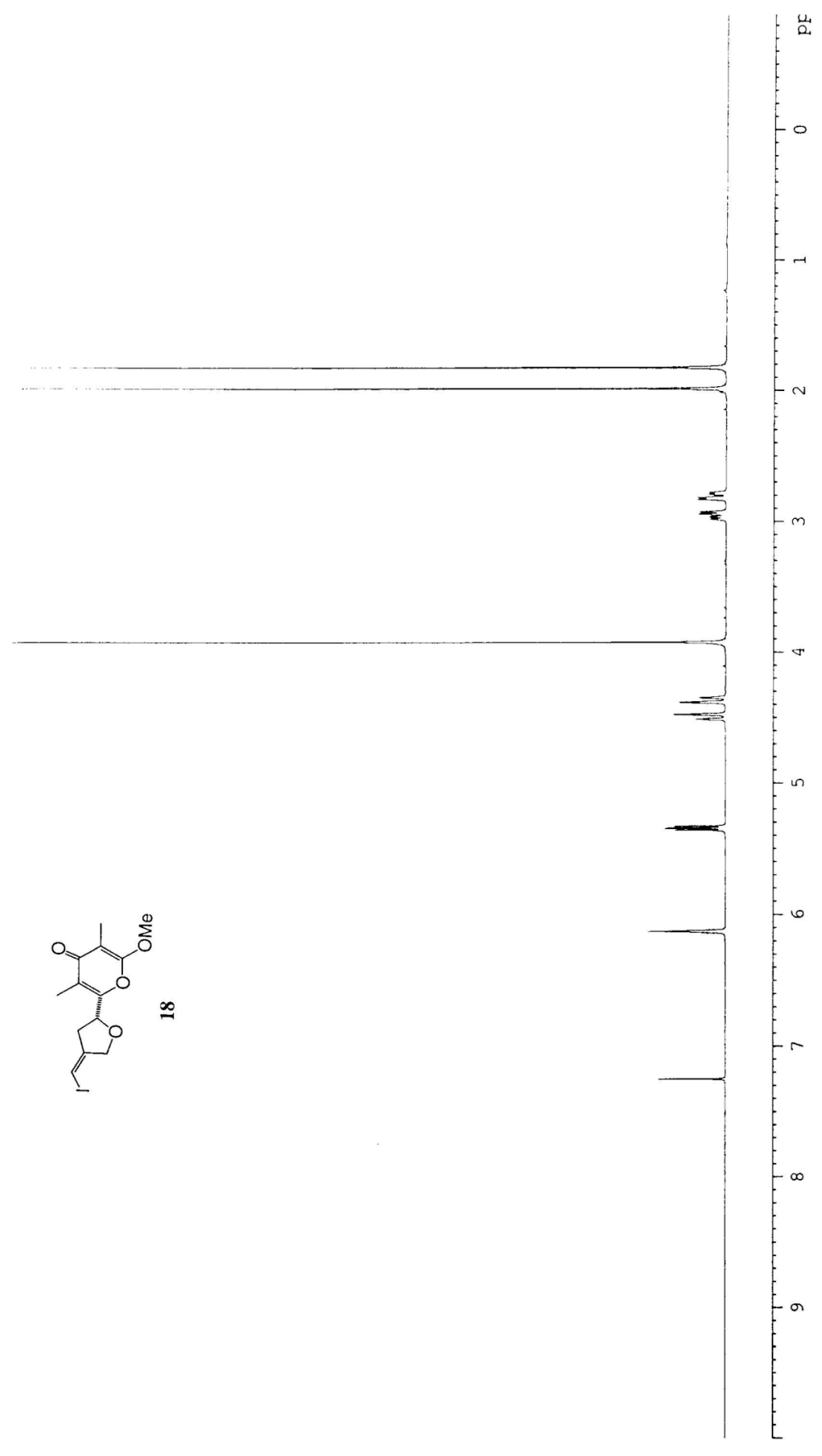




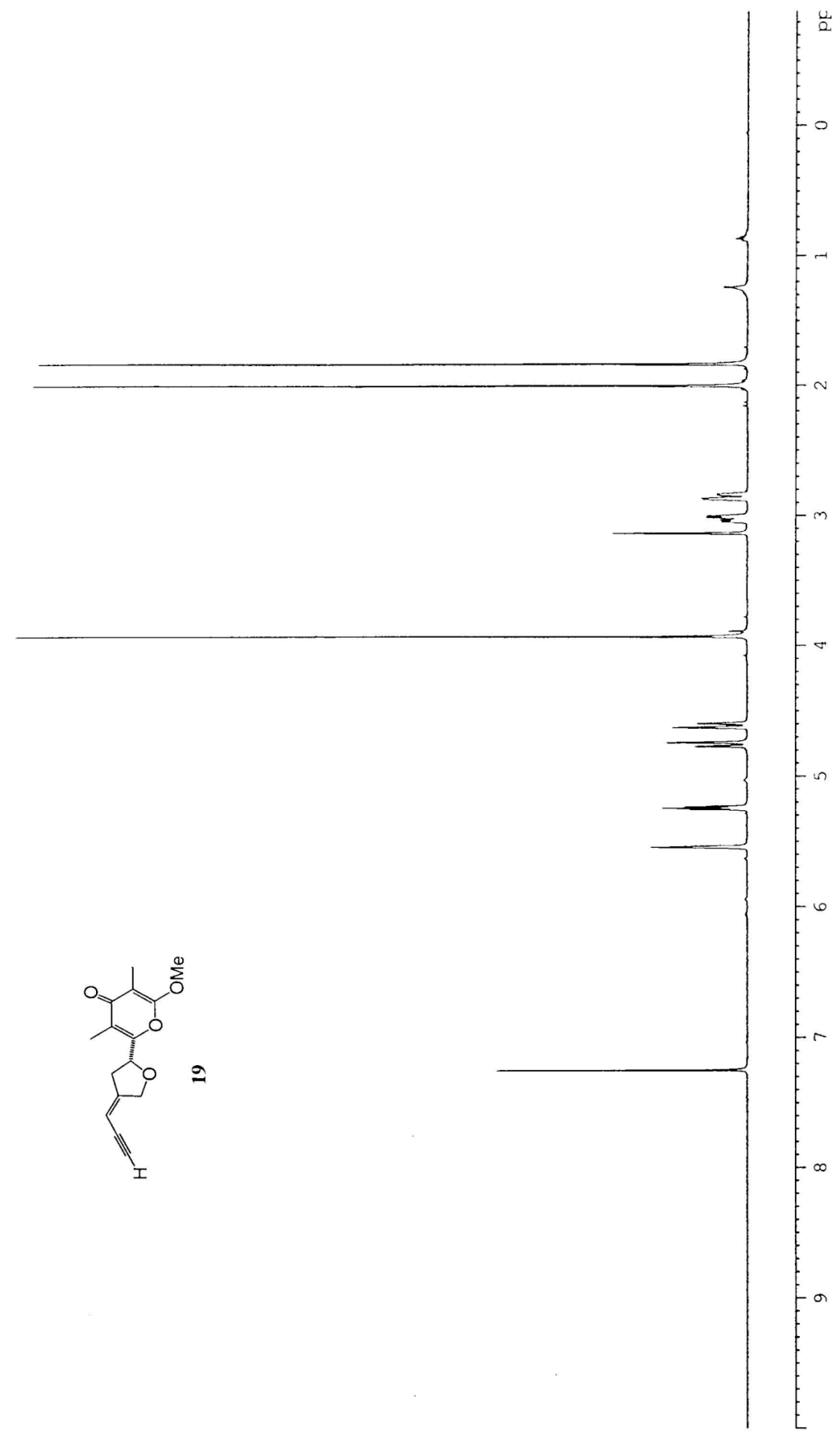




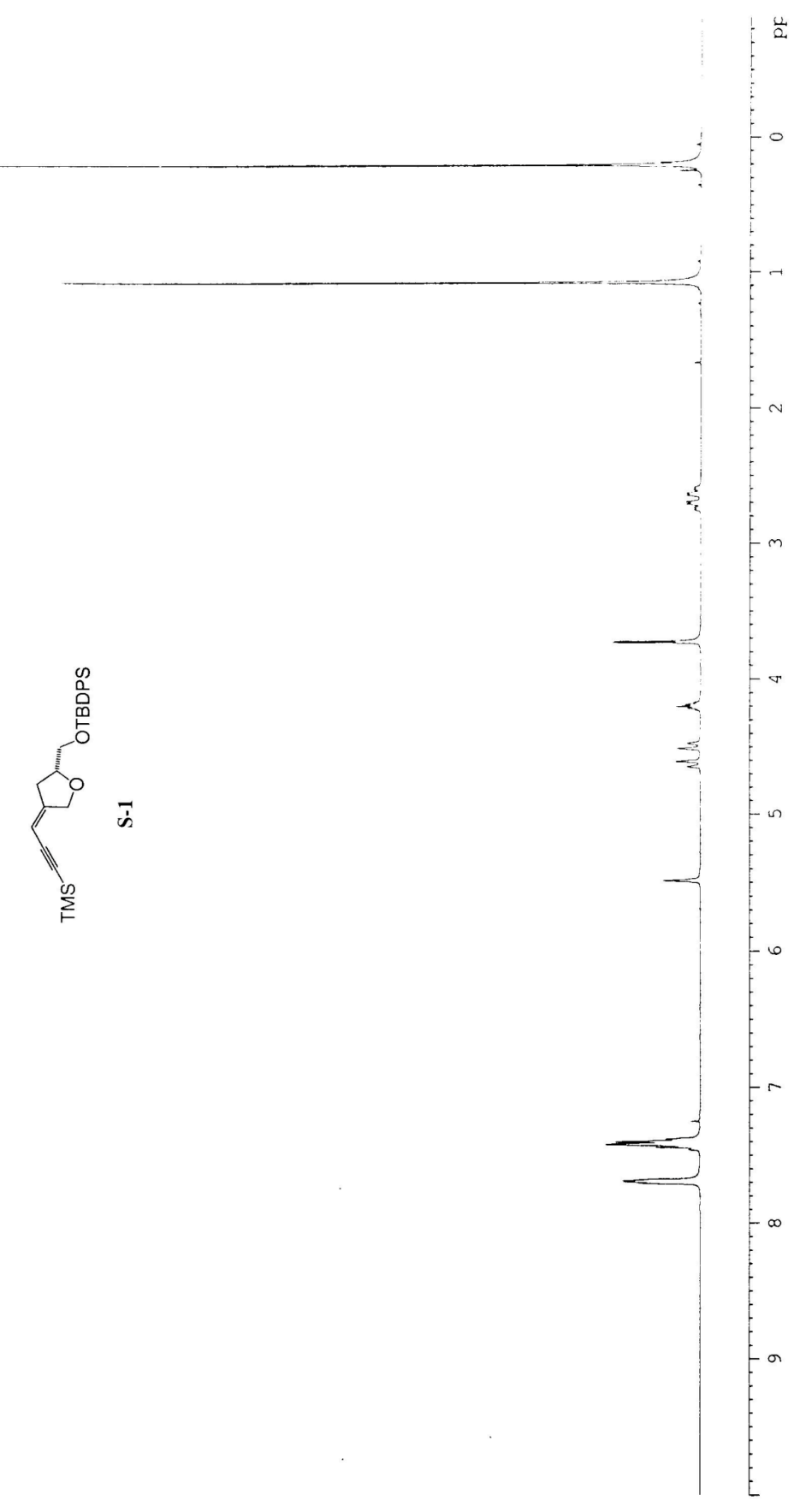




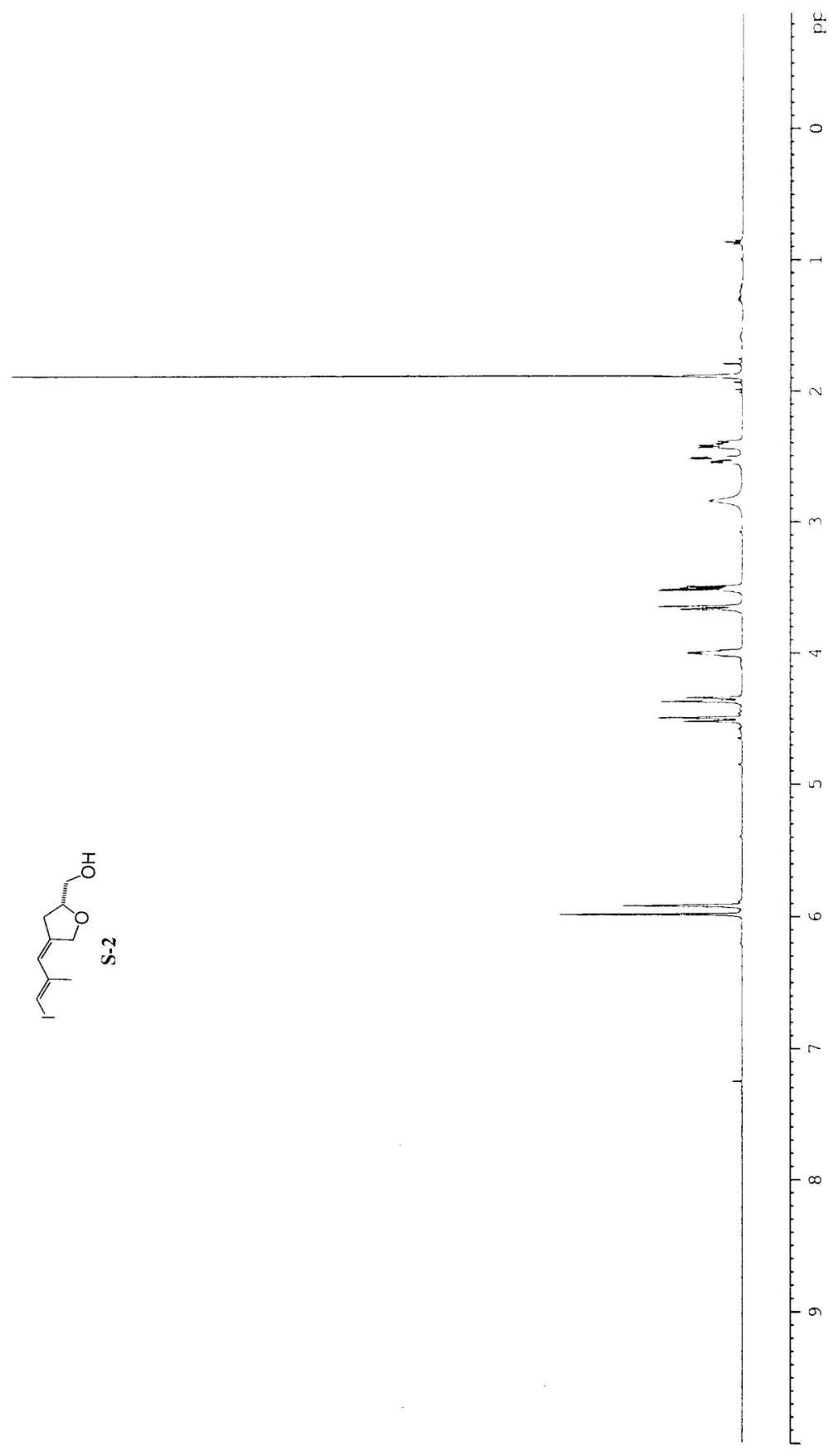




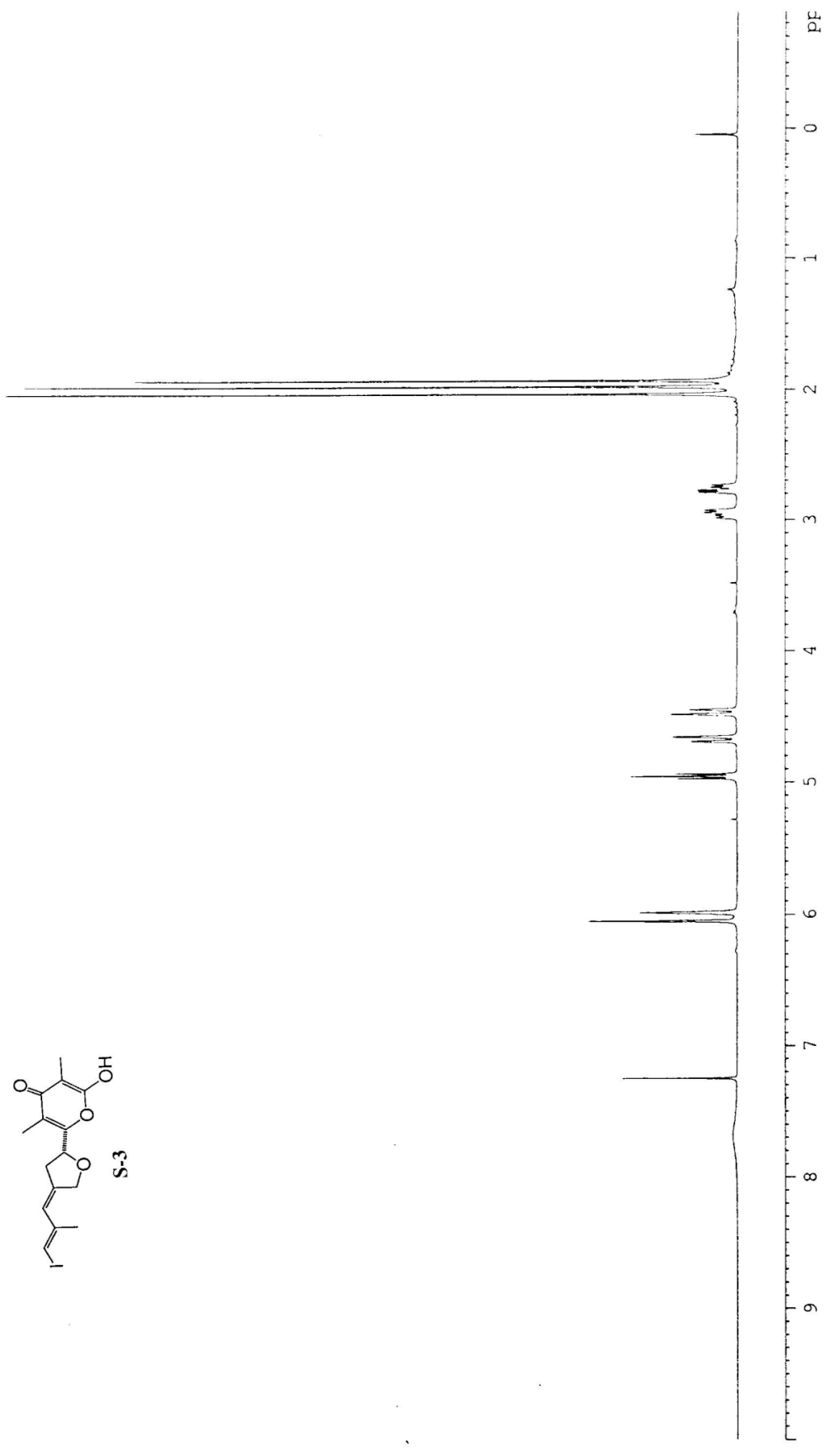




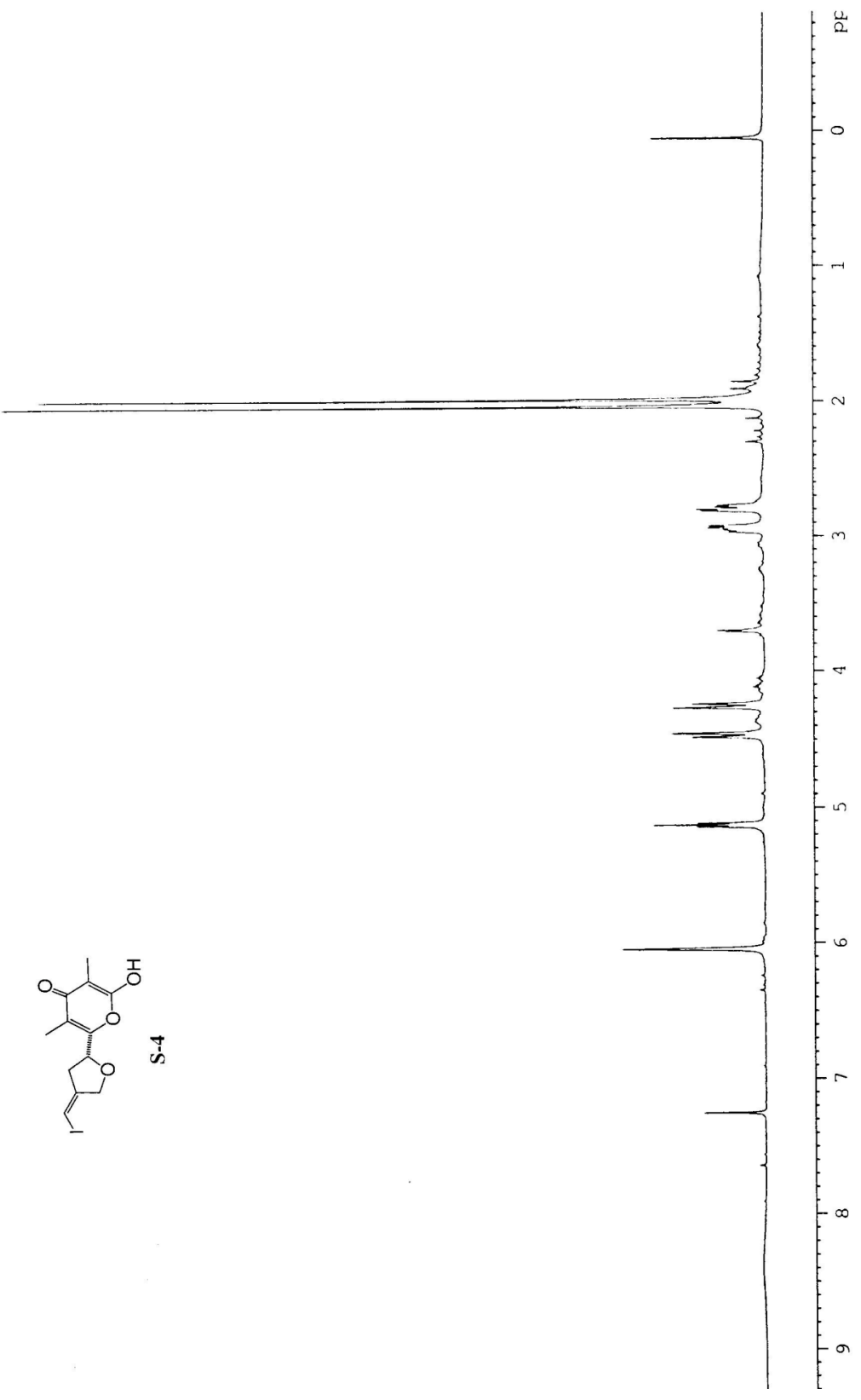




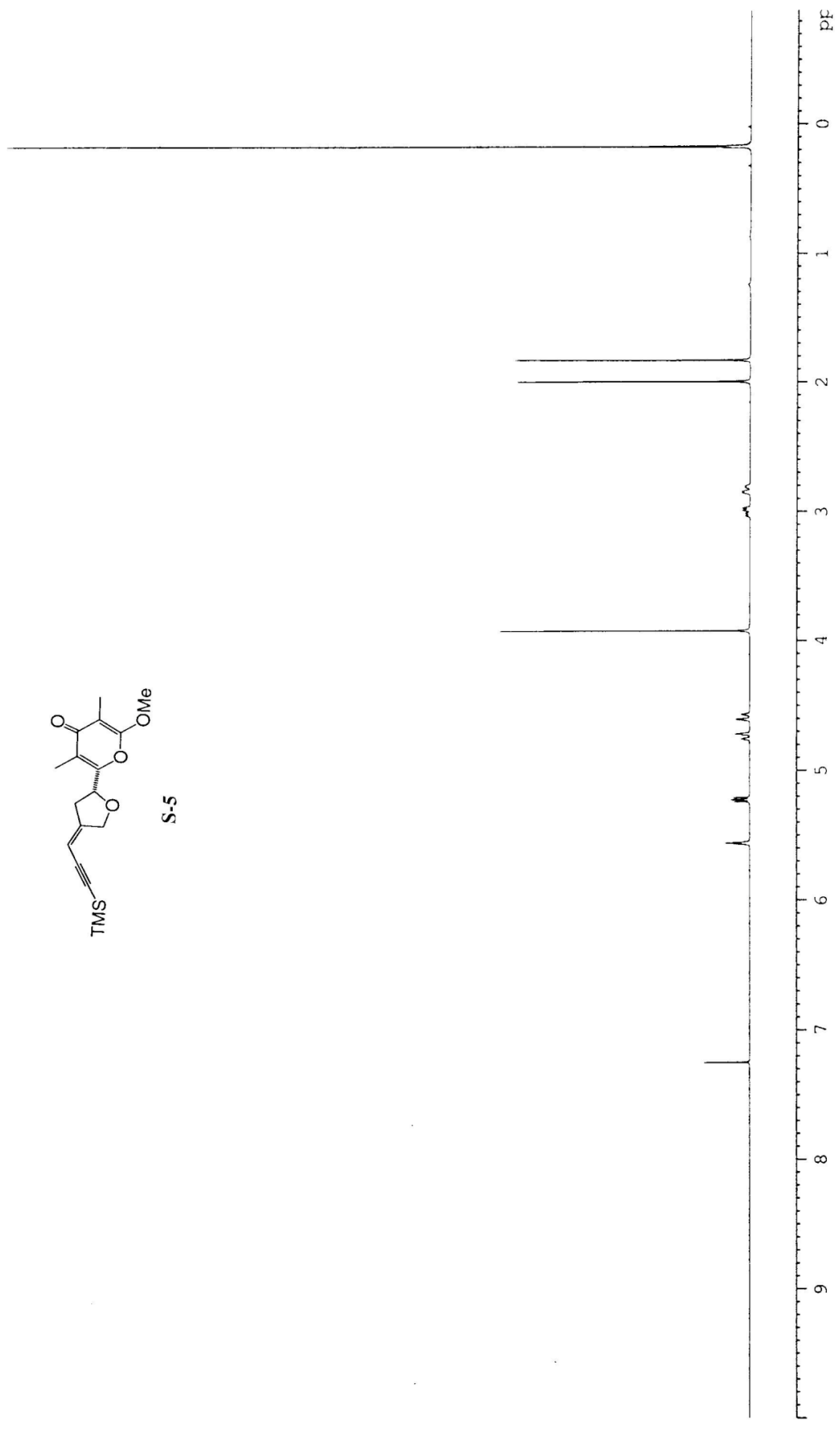




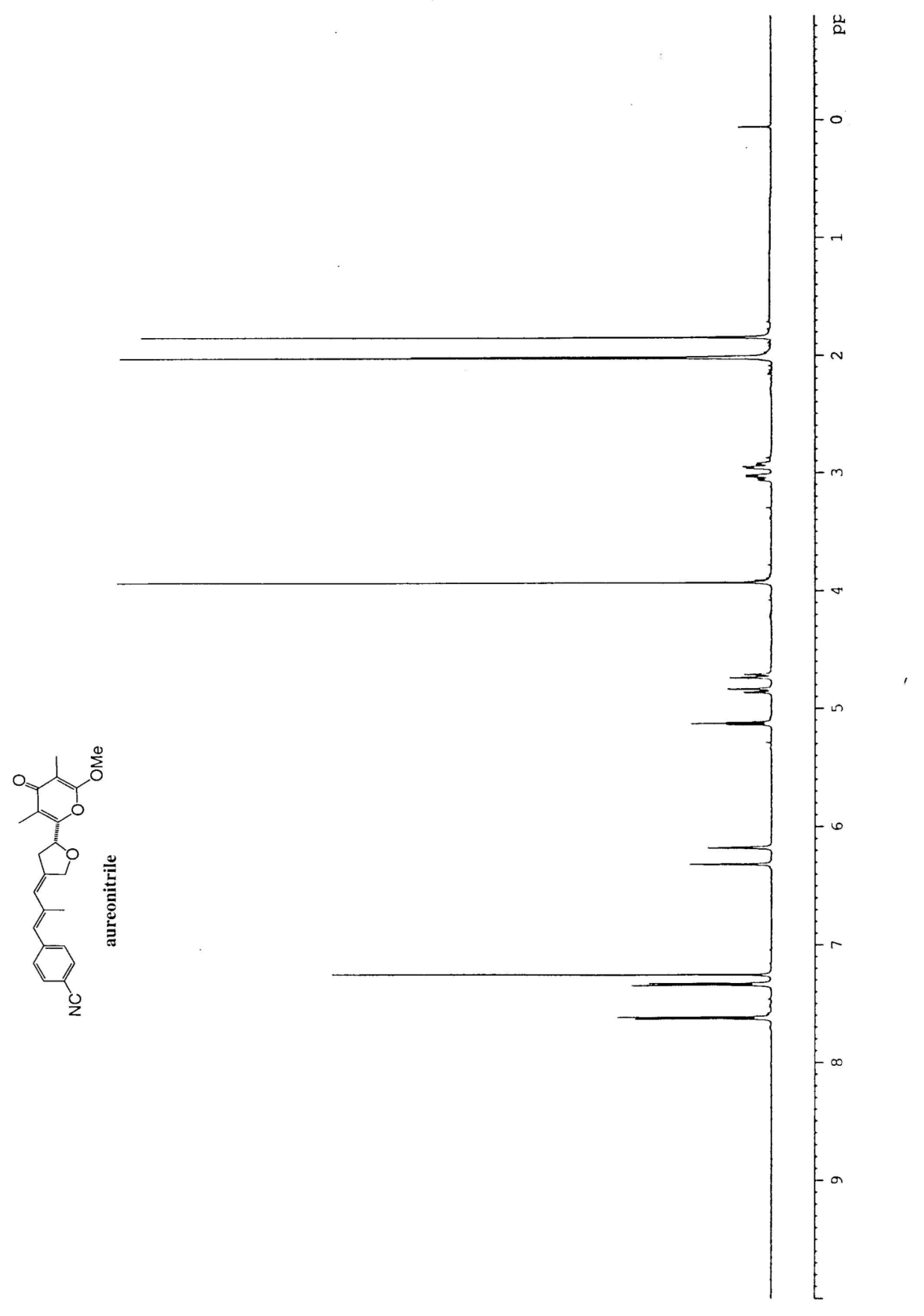




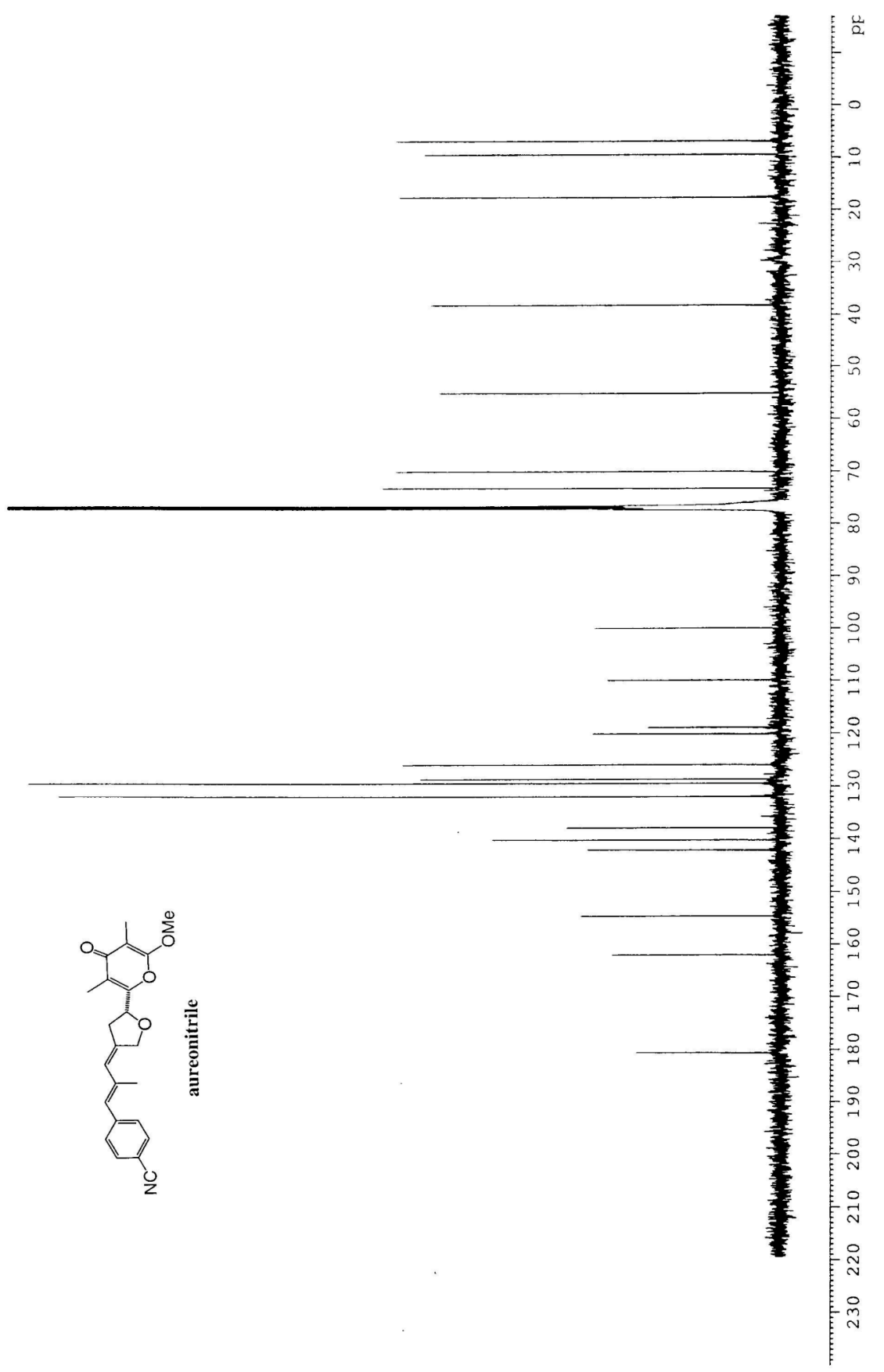




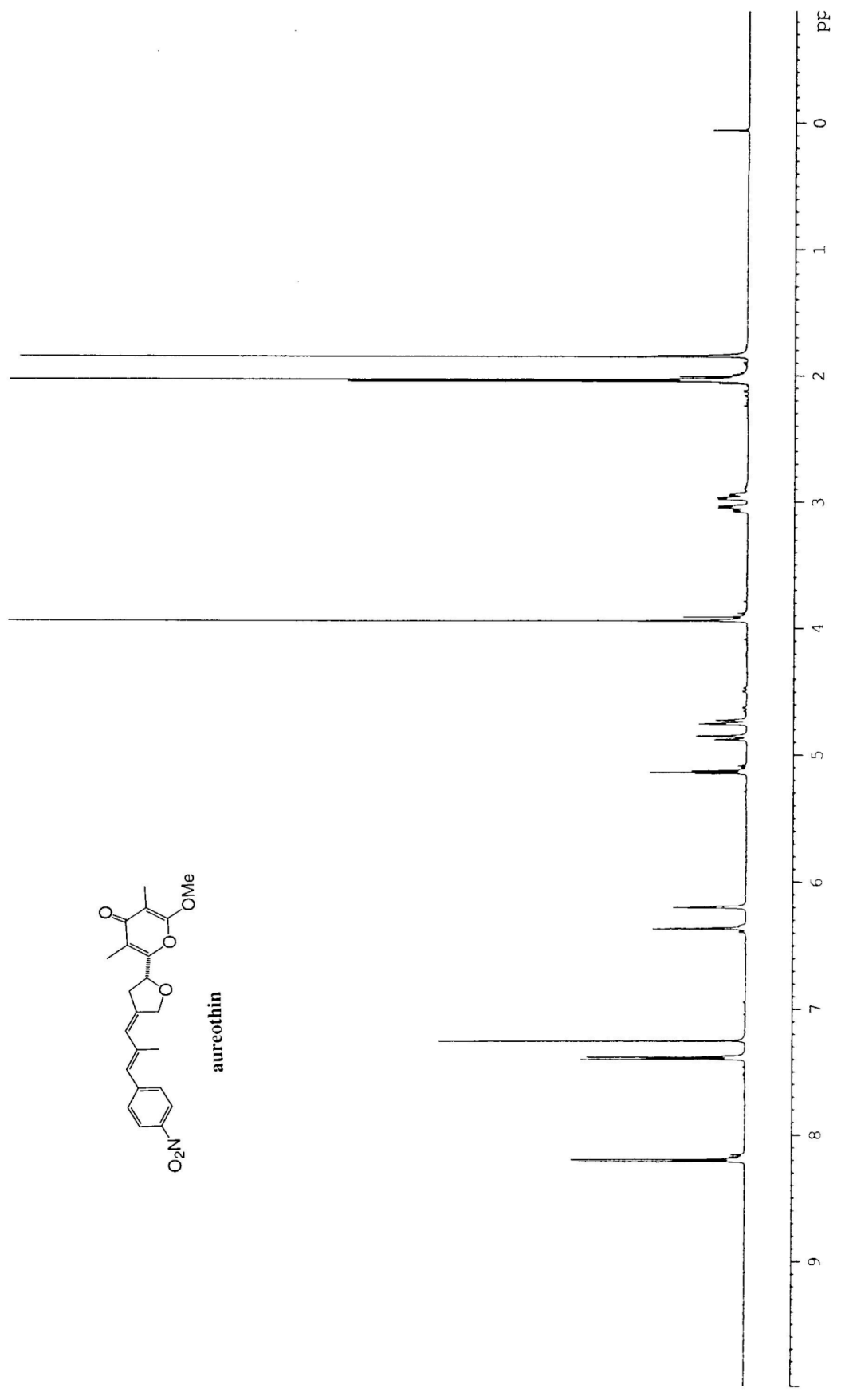




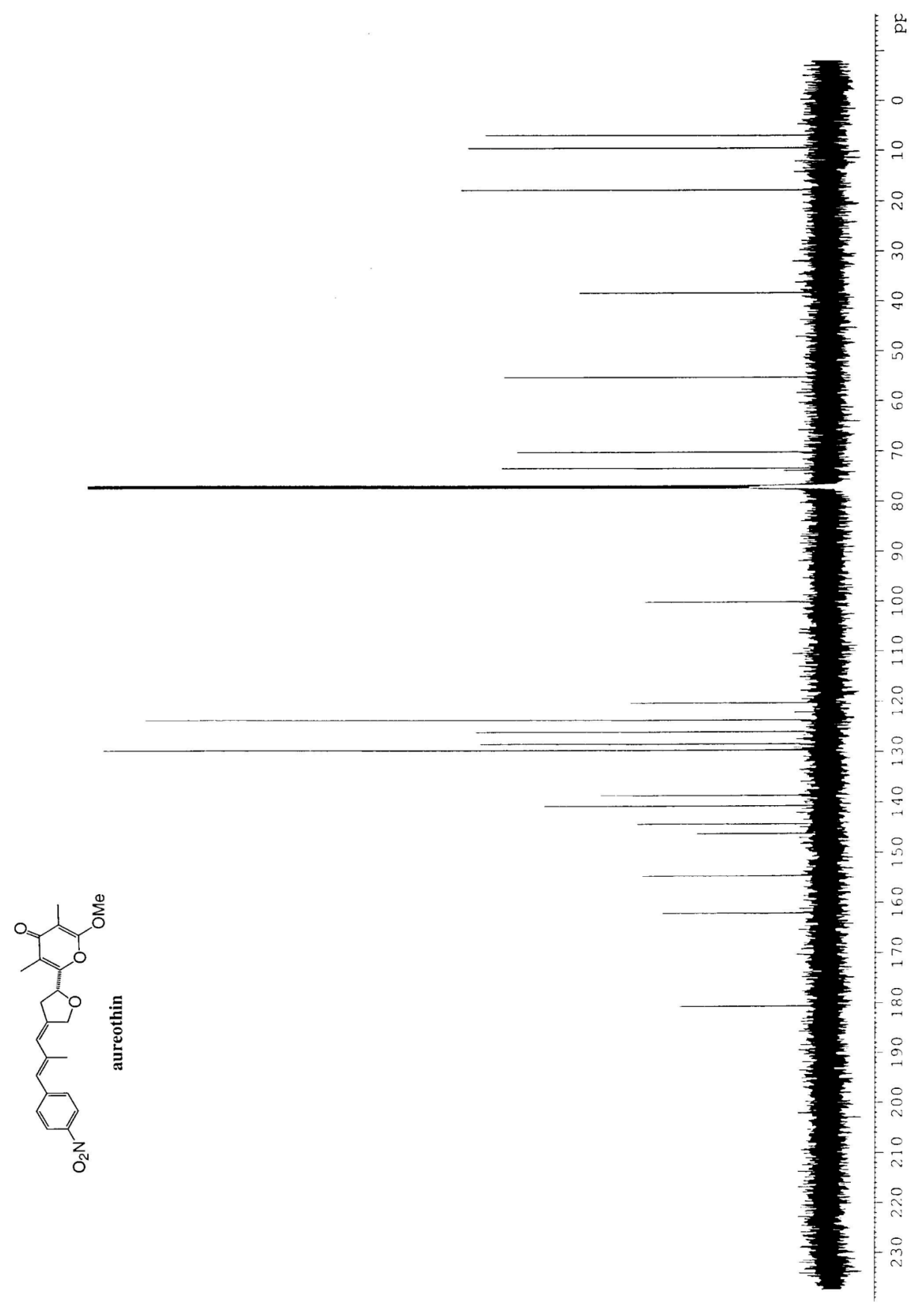

S35 


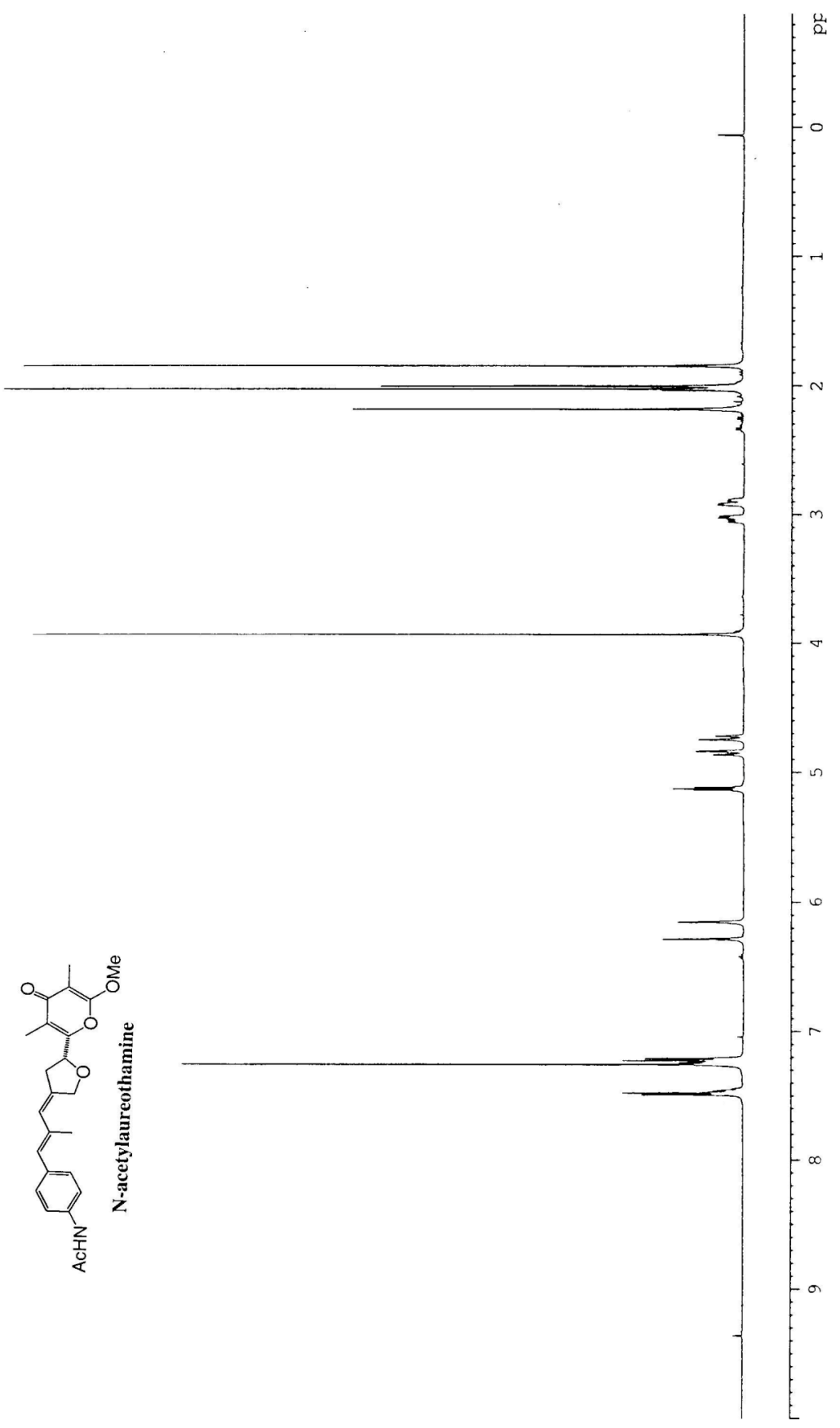




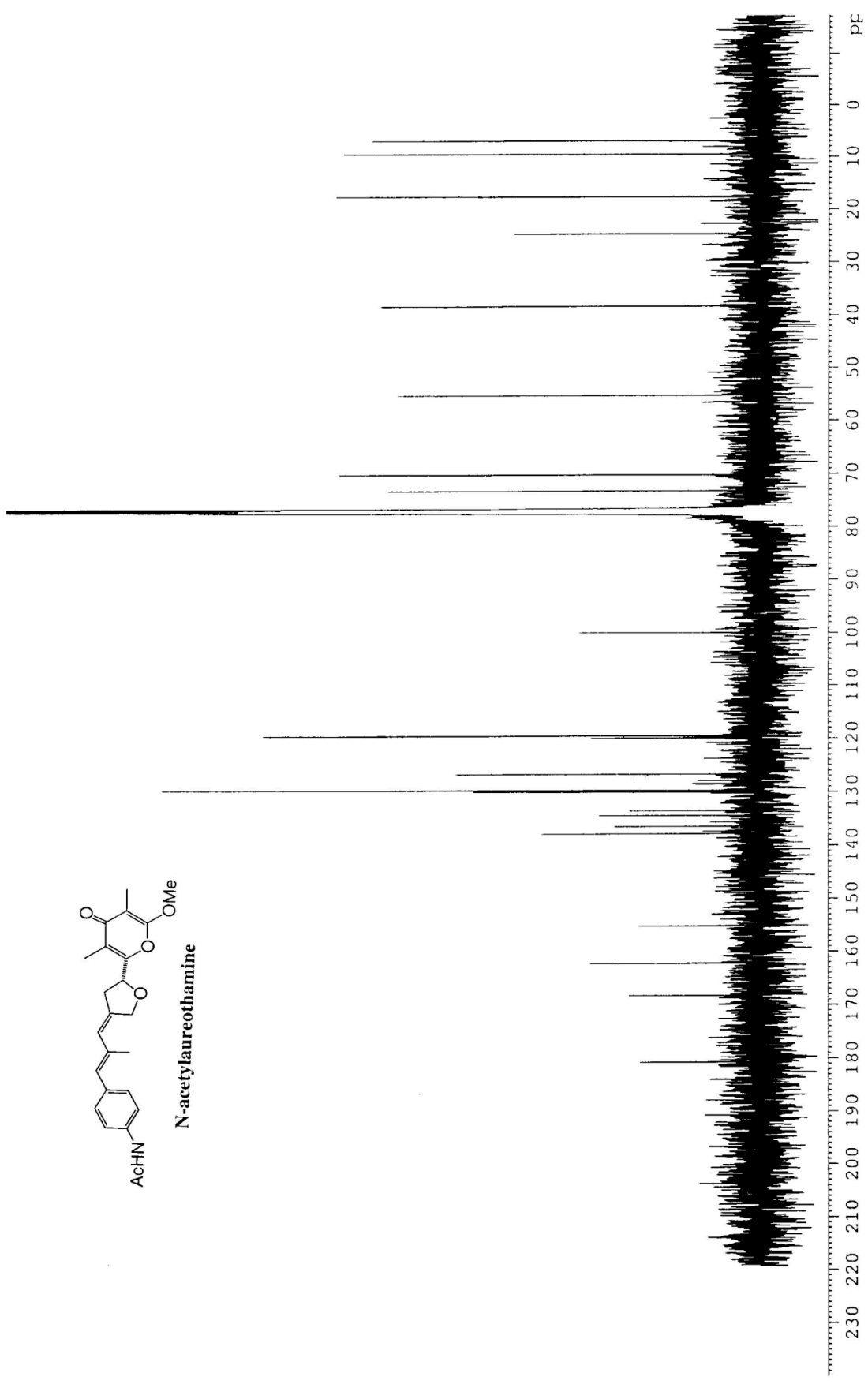

